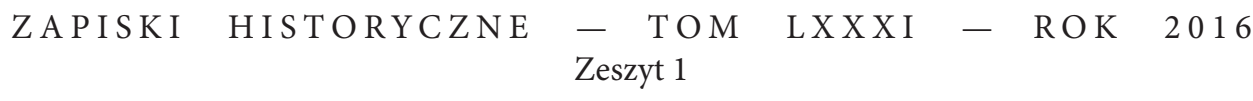

http://dx.doi.org/10.15762/ZH.2016.60

SEAWOMIR KOŚCIELAK

(University of Gdańsk)

\title{
BACKGROUND, RELATIVES AND THE ORIGIN \\ OF THE COUNTERFEIT ACTIVITY \\ OF KRZYSZTOF STANISŁAW JANIKOWSKI ${ }^{*}$
}

Key words: Royal Prussia, Władysław IV, justice, forgers of documents, minor nobility social advancement and degradation

\section{PREVIOUS RESEARCH ON KRZYSZTOF STANISŁAW JANIKOWSKI}

Krzysztof Stanisław Janikowski lived in Poland (the Crown) in the first half of the $17^{\text {th }}$ century. He came from the petty gentry living in Prussia near Gdańsk, the largest city of the Polish-Lithuanian Commonwealth at that time. He went down in history as one of the most audacious fraudsters and forgers of documents. He published dozens of fraudulent legal acts, useful to highest dignitaries of the state, church institutions, as well as private persons, nobles and burghers. He made a remarkable career in the Republic of Poland, and became an influential and apparently respected man. He was appointed the royal secretary and was backed by the wealthy in disputes relating to family fortunes. Before unmasking his counterfeits with considerable help from the Gdańsk residents, he was killed in a family revenge attack, the so-called zajazd (foray), at the end of August 1647.

The $17^{\text {th }}$ century forger of documents, Krzysztof Stanisław Janikowski, is comparatively well known in Polish historiography. This crook and criminal offender on a unique scale has even gained a place in the Polish Biographical Dictionary. ${ }^{1}$ There is as yet no modern monograph showing the social, political and religious context of his activities, or analysing the reasons and conditions, which pushed him into a life of crime or the circumstances facilitating his initial success. In the whole of his achievements as a forger, deeper analysis is required of aspects such

* This article is an English version of the article which appeared in "Zapiski Historyczne", vol. 81, 2016. Translation was part of the task "The publication of 'Zapiski Historyczne' in the English language version, Vol. 81, 2016, books (zeszyt 1-4)" financed as part of the agreement 698/P-DUN/2016 with the resources of the Ministry of Science and Higher Education devoted to the popularization of science.

${ }^{1}$ Józef Rumiński, Janikowski Krzysztof Stanisław (ok. 1615-1647), [in:] Polski słownik biograficzny (further cit. PSB), vol. 10, Wrocław-Warszawa-Kraków 1962-1964, pp. 518-519. 
as the extremely complex issue of the private and public relationships between the forger and his family from Gdańsk but also some townspeople in Gdańsk. A combination of events, including in particular his pattern of economic activity and excessive personal ambitions: the conclusion of contracts, agreements, marriage, the desire to make a career in administration, led K. S. Janikowski to a series of personal conflicts and outstanding property claims, forced him to manoeuvre in the contemporary legal system, and as a result ending up with huge debts, impossible to pay off and encumbered with judicial sanctions.

This article therefore attempts to discuss the origin, youth and immediate surroundings of the forger, from the moment of his birth to the alleged discovery of the box of documents. It will attempt to present his family background and other problems that so far have not been covered by recent historiography, and will also provide a more detailed analysis of the first criminal accomplishments of this member of the Polish gentry, facts known and widely commented on, long before he began to demonstrate in their fullness his deceptive skills. The sources dawn on include court records of the period relating to various disputes as well as his banishment and loss of civil rights by the sentence known as infamia. Several scholars have in the past interested themselves in the activities of Krzysztof Stanisław Janikowski. Already in the $18^{\text {th }}$ century these included the historian and lawyer from Gdańsk Gottfried Lengnich, ${ }^{2}$ the German philosopher and biographer of the Great Elector, Samuel Pufendorf, ${ }^{3}$ the Prussian historian Johann Carl Conrad Oelrichs. ${ }^{4}$ At the beginning of the $19^{\text {th }}$ century the deeds of K.S. Janikowski were described by the champion of the power and culture of the city on the Motława, Gotthilf Löschin. ${ }^{5}$ It was only Polish historians towards the middle of that century who attempted a deeper analysis of the archival material available to them that presented the stormy history of the life of the forger and his deceptions. Among these researchers, mention should be made of Stanisław Lisowski ${ }^{6}$ and Father Ignacy Polkowski, a veteran historian-archivist, bibliophile and collector from Galicia. ${ }^{7}$ At the beginning of the twentieth century, Zygmunt Gloger mentioned K. S. Janikowski and his deeds in his Encyklopedia staropolska, ${ }^{8}$ and the Gdańsk historian,

${ }^{2}$ Gottfried Lengnich, Geschichte der Preussischen Lande Königlich Polnischen Antheils unter der Regierung Vladislai IV, [Th. VI], Danzig 1729, pp. 236-240, 251, 257.

${ }^{3}$ Samuel Pufendorf, De rebus gestis Friderici Wilhelmi, Magni Electoris Brandenburgici, commentatorium, Lipsiae-Berolini 1733, p. 93.

${ }^{4}$ Johann Carl Conrad OelRichs, Fortgesetzte historisch diplomatische Beiträge zur Geschichte der Gelertheit besonders in Herzogthum Pommern, Berlin 1770.

${ }^{5}$ Gotthilf Löschin, Geschichte Danzigs von der ältesten bis zur neusten Zeit, Th. 2, Danzig 1822, pp. 333-334.

${ }^{6}$ Stanisław Lisowski, Wiadomość o dwóch fałszerzach źródeł historii polskiej w XVII i XVIII w., [in:] Album literackie, edited by Kazimierz Władysław WójcickI, vol. 2, Warszawa 1849, p. 344.

${ }^{7}$ Ks. Ignacy Polkowski, Krzysztof Stanisław Janikowski, fałszerz dokumentów polskich w XVII wieku, Rocznik dla Archeologów, Numizmatyków i Bibliografów Polskich, vol. 1: 1869, Kraków 1870, pp. $28-47$.

${ }^{8}$ Zygmunt Gloger, Encyklopedia staropolska ilustrowana, vol. 2, Warszawa 1901, pp. 142-143. 
expert on Pomeranian archives and publisher of many source documents not only of the modern period, Max Bär attempted to evaluate and classify K. S. Janikowski's forgeries. ${ }^{9}$ Contemporary historians have also studied him - from various points of view - such as Janusz Tazbir, ${ }^{10}$ or more recently Wiesław Nowosad. ${ }^{11}$ The person and deeds of the forger have also appeared in the context of discussions of the complicated situation between the different faiths in Gdańsk and in Royal Prussia, in which he became involved due to his forgeries, ${ }^{12}$ which has aroused the interest of writers of popular accounts of local history. ${ }^{13}$ In the final analysis, the fullest account until now of the current state of knowledge on the topic of K. S. Janikowski and his deceptions has been presented by the above-mentioned author of the biographical note in the Polish Biographical Dictionary, Józef Rumiński, and (apart from in the above-cited publication) his conclusions can also be found in an article published almost 50 years ago in the periodical "Zapiski Historyczne."14

Józef Rumiński - as he himself notes in the introduction to his text - based his research above all on the documents deposited in the State Archives in Gdańsk and not only in the "Dossier on Forgeries" about K. S. Janikowski in the collection of documents labelled "Letters and writings of the nobility after $1525,{ }^{15}$ but also in the collection in the Gdańsk town records referring to settlements between heirs of the estates of Royal Prussia ${ }^{16}$ and a few other documents. ${ }^{17}$ He concentrated however, like his predecessors, on the history of the astonishing career of forgery of K. S. Janikowski, facilitated by the protection he was afforded by the royal court. Józef Rumiński introduced information on many previously unknown episodes

${ }^{9}$ Max Bär, Über eine Privilegienfälschung in Westpreussen, Mittheilungen des Westpreussischen Geschichtsvereins, Jg. 2: 1903, Nr. 1, pp. 3-11.

${ }^{10}$ Janusz TAZBIR, Spotkania $z$ historia, Warszawa 1979, pp. 228-230.

${ }^{11}$ Wiesław Nowosad, Archiwa szlachty Prus Królewskich, Toruń 2005, pp. 123-125.

${ }^{12}$ See, for example, Sławomir Kościelak, Jezuici w Gdańsku od drugiej połowy XVI do końca XVIII wieku, Gdańsk-Kraków 2003, pp. 296-297; idem, Katolicy w protestanckim Gdańsku od drugiej połowy XVI do końca XVIII wieku, Gdańsk 2012, pp. 115-116; Irena МАKarcZYк, Tomasz Ujejski (1612-1689), biskup kijowski, prepozyt warmiński, jezuita (Rozprawy i Materiały Ośrodka Badań Naukowych im. Wojciecha Kętrzyńskiego w Olszynie, nr 228), Olsztyn 2005, pp. 218-221.

${ }^{13}$ See, for example, Jarosław Mүкошsкi, Jak Gdańsk zemścił się na ulubionym fałszerzu króla Władysława IV, Dziennik Bałtycki, nr 165 (21189). 18 July 2014, pp. 26-27.

${ }^{14}$ Józef Rumiński, Fałszerstwa dokumentów Krzysztofa Stanisława Janikowskiego w Prusach Królewskich w połowie XVII wieku, Zapiski Historyczne, vol. 30: 1965, fasc. 3, pp. 37-66.

${ }^{15}$ Archiwum Państwowe w Gdańsku [State Archives in Gdańsk] (further cit. APGd), document number 300, 52/946, 947, 948, 949, 950, 951, 952, 953, 954, 955, 956, 957, 958, 959, 960, 961, 962, 963, 964. Józef Rumiński seems to have known only a few of these documents, selected by himself and made use of these folders when they were still unpaginated. Therefore his normal practice was to make reference to the whole volume that has eased the verification of the information he supplies.

${ }^{16}$ APGd, document number 300, 29/127, 128, 129, 132, 133, 134, 136, 137, 167.

${ }^{17}$ Ibid., document number 361/1, a forgery made for the Dominican monastery in Tczew; also slight mentions in the section in the groups of records concerning Gdańsk: "Bibliotheca Archivi" (document number 300, R/Vv, 173, k. 95; 300, R/Vv, 71, k. 100) and "Recesy Ordynków" (document number 300, 10/26, k. 653, 658). 
from the life of Krzysztof Stanisław into the public forum, also from the period of his youth, not treating this, however, as the key to the formation of the mentality of a fraudster. He also was the writer who discussed most fully until now, though not without errors, his family connections and relations, many of them collaborators in the criminal activities. In the final paragraphs of his article, J. Rumiński concentrated on presenting the story of the official dismantling of the believability of the documents that K. S. Janikowski had prepared. He came to the conclusion that the investigations into Janikowskis damaging procedures had in fact never been fully completed, he was not judged, and his deceits were not even condemned, even though the matter was discussed in meetings of the parliament (Sejms) and local parliaments (Sejmiks) at least as late as $1672 .{ }^{18}$ It is worth noting, however, that J. Rumiński's study lacks deeper analysis, reflection and summaries. There is even a lack of a clear and explicit presentation of the obvious thesis that the case was a kind of $17^{\text {th }}$-century scandal on a grand scale, in which were involved - for different reasons - the highest personalities of the state of the Republic at that time and that ultimately for this reason it was never fully explained.

There is much more archival material on which one could base a much more comprehensive study of K. S. Janikowski than that achieved by J. Rumiński using the sources he collected. Full use has not yet been made of some of the material that is available, such as the "dossier on the forgeries" - that is 19 folders of loose and bound documents describing the youth and adulthood of K. S. Janikowski and gathering evidence of his crimes. ${ }^{19}$ Especially interesting are the documents that contain information about K. S. Janikowski's siblings, including those documenting his relationship with the eldest of his brothers, Jan Stanisław. The documents in the State Archives in Gdańsk are also worth deeper analysis, such as the records of municipal assemblies in which we find records of more meetings than those allowed for by J. Rumiński, in which the case of K. S. Janikowski and his widow were discussed. ${ }^{20}$ There are also very many more mention of Janikowski's forgeries than Rumiński acknowledges in the section "Bibliotheca Archivi."21 There is a total lack of mention by J. Rumiński of the valuable information about the financial aspects of the relationships between the Janikowski family and the municipal authorities

${ }^{18}$ J. RumiŃski, Fałszerstwa, pp. 62-64.

${ }^{19}$ In the group of documents entitled "Letters and writings of the nobility after 1525" (APGd, document number 300,52 ) there is an interesting folder with the number 1316 . There is a total lack of mentions among the documents discussed by J. Rumiński of any of a broad series concerning the brother of the forger, Jan Stanisław Janikowski, lay judge and member of the Sejm, for example the "Memoriale debitorum..." of the same (see APGd, document number 300, 52/948, pp. 7-18). This is something like an accounts book, with nine pages filled with simple tables with the listing of expenditure. The notes are kept rather chaotically, and mostly without dates (though it may be expected that they were made successively in chronological order). These records provide much new detailed information on the origins of the Janikowskis, their financial status, family connections and problems.

${ }^{20}$ APGd, document number 300, 10/27, k. 39, 486; document number 300, 10/30, k. 69v, 76v.

${ }^{21}$ Ibid., document number 300, R/T vol. 7, pp. 461-462, 571; document number 300, R/Vv, 140 etc. 
of Gdańsk in the account books of the Gdańsk Kämmerei, beginning already in $1619,{ }^{22}$ and ending in $1671,{ }^{23}$ with their apogee falling in the critical year $1647 .{ }^{24}$ To establish the chronology of the oldest traces of the Janikowskis in Royal Prussia and the age of the forger it would be worth also refer to the municipal court records from the Gdańsk region, including Puck and Kościerzyna. ${ }^{25}$ The material in the library of the Gdańsk branch of the Polish Academy of Sciences has great potential, although some of it consists of duplicates of items already known from the State Archives in Gdańsk. ${ }^{26}$ Useful material can undoubtedly also be found in other Polish and foreign archives and libraries, and therefore any further investigation needs to be undertaken on a broad front and also in an interdisciplinary fashion.

\section{THE ORIGIN OF THE JANIKOWSKIS - ANCESTORS, UNCLES AND COUSINS OF THE FORGER}

According to J. Rumiński, the Janikowski family of Łostowice used the Korab coat of arms. ${ }^{27}$ This is however a mistaken view. On the documents indicated by J. Rumiński, signed by the older brother of the forger, a lay-judge of Tczew, Jan Stanisław, one can clearly see the Jastrzębiec coat of arms ${ }^{28}$ In his armorial, Jan Karol Dachnowski states that it was customary to write the family name as Stańczyk, and indeed such a regularity can be observed in some extracts from the records of the regional court from the years 1620-1641. ${ }^{29}$ The name Stanisław was often met in the clan and was almost treated like a nickname.

${ }^{22}$ Ibid., document number 300, 12/49, pp. 119, 129, 289, 307.

${ }^{23}$ Ibid., document number 300, 12/111, p. 117.

${ }^{24}$ Ibid., document number $300,12 / 79$, pp. 79, 89; document number, 300, 12/82, p. 141; document number $300,12 / 83$, pp. 59, 60, 120, 164, 166, 182; etc.

${ }^{25}$ Ibid., document number 519/46 (court records [ksiega ławnicza] of Puck for the years 15841618); in the Biblioteka Ossolińskich we Wrocławiu [Ossolineum Library in Wrocław] (further cit. B.O.), manuscript 3179 II (court records [księga ławnicza] of Kościerzyna for the years 1622-1629). I would like to thank here the author of a publisher's review of this text for leading me to this most interesting piece of evidence among the scattered material concerning the subject discussed here.

${ }^{26}$ Including Biblioteka Gdańska PAN, Ms 495, k. 116-116v, 119a-120a; Ms 740, k. 73v; Ms Uph. fol. 26, pp. 301-303; Ms Uph. fol. 140, after p. 47 etc.

${ }^{27}$ J. Rumiński, Janikowski Krzysztof Stanisław, p. 518; idem, Fałszerstwa, p. 38.

${ }^{28}$ Including APGd, document number 300, 52/948, p. 50, a document of Jan Stanisław Janikowski with the date 1627. On this one can clearly see an inverted horseshoe knight's cross in the middle, characteristic of the Jastrzębiec coat of arms. The Korab coat of arms contains, as the name suggests a representation of a ship (korab) with a crenellated masonry tower, there is no way therefore to confuse the two. Janikowski is also assigned the Jastrzębiec coat of arms by: Jan Karol DAchnowSKI, Herbarz szlachty Prus Królewskich z XVII wieku, published by Zdzisław Pentek, Kórnik 1995, p. 327; Kasper Niesiecki, Herbarz Polski, vol. 4, published by Jan Nepomucen Bobrowicz, Lipsk 1839, p. 435; Adam Boniecki, Herbarz Polski, vol. 8, Warszawa 1908, pp. 188-191; Urzędnicy Prus Królewskich XV-XVIII wieku. Spisy, prepared by Krzysztof MikULSKI, Wrocław-Warszawa-Kraków 1990, p. 209.

${ }^{29}$ For example APGd, document number 300, 52/949, p. 13. 
The parents of Krzysztof Stanisław, Stanisław Janikowski and Katarzyna (née Sobańska), were born into the nobility. The only source citing the origins of Stanisław is a somewhat imprecise note in J. K. Dachnowski's armorial, according to which the Janikowskis were a relatively new arrival on the scene in Royal Prussia. According to him, they had come from the region of Sieradz, and that it was Stanisław, the father of the forger Krzysztof Stanisław, who had been first to settle in the region (but J. K. Dachnowski did not know where). ${ }^{30}$ Somewhat later, Kasper Niesiecki suggested that the family had immigrated to Royal Prussia from the territory of Opoczno in the Sandomierz region. The suggestions contained in the armorials are confirmed by some of the preserved Janikowski family documents. Jan Stanisław, the oldest brother of the forger wrote in his account book, which he had began in 1620 , that just after the death of his father he had to undertake a trip to "Opoczno Janikowicz" in order to obtain documents confirming his noble birth. ${ }^{31}$ According to the armorial of Adam Boniecki, this Janikowice was jointly owned in 1577 with three other members of the nobility by three Janikowski brothers, Andrzej, Bartłomiej and Wawrzyniec Stańczyk. ${ }^{32}$ Due to the nickname formed from the Christian name Stanisław, one may suspect that it was precisely the latter who was the protoplast of the branch of the family that later settled in Royal Prussia and was the grandfather of Krzysztof Stanisław. The high degree of fragmentation of the property of Janikowice would certainly have encouraged members of the family to seek better conditions for life in other regions of the country. Apart from settling in Royal Prussia, there may also have been an exodus in the direction of Kalisz, where between 1579 and 1596 there are records that a Bartłomiej Janikowski (perhaps the brother of Janikowski of the same name?) was joint-owner of half of Janików (Rajsko commune) and part of that Rajsko. ${ }^{33}$ The "Kalisz" Janikowskis might very well have been very close relations of the branch of the family

${ }^{30}$ J. K. DAchnowski, op. cit., p. 327. Jan Karol Dachnowski did not know his name, but wrote that the Janikowskis "used to write their name Stańczyk" which may be considered a camouflaged version of the name Stanisław - which was a popular one among the Pomeranian branch of the Janikowski family. The creation of such nicknames was typical for this region. The presence of the Janikowski family in the northern regions of Pomerania has not yet been noted by publications such as Przemysław Pragert Herbarz szlachty kaszubskiej (vol. 1-4, Gdańsk 2005-2015), which makes it even more visible that they really were new arrivals in the region.

${ }^{31}$ APGd, document number 300, 52/948, "Memoriale debitorum...", p. 9. The name given in the record seems to be somewhat distorted, perhaps this was meant to read "to Janikowice near Opoczno."

${ }^{32}$ See A. Boniecki, op. cit., p. 189.

${ }^{33}$ Ibid., op.cit., p. 190. See also: Grodzkie i Ziemskie > Kalisz >Rezygnacje, XVI wiek, [in:] Teki Dworzaczka. Materiały historyczno-genealogiczne do dziejów szlachty wielkopolskiej XV-XX wieku, prepared by Jerzy WisŁocki, Adam Bieniaszewski, Rafał T. Prinke, Michał Prinke, Biblioteka Kórnicka PAN, Kórnik-Poznań 2004 (http://teki.bkpan.poznan.pl; accessed 2 X 2014), position 5093 (nr 4) - 1576, position 1555 (nr 6) - 1592, position 1837 (nr 7) - 1596. In addition to the portions of Janików and Rajsko, he also owner fields in nearby Złotniki Małe. The Teki Dworzaczka cited above inform us that in 1576 Bartłomiej Janikowski had a wife Petronella (née Stobiecka) while in 1592 he guaranteed from the aforementioned estates a dowry to the next wife, Katarzyna (née Laszewska). 
settled in Royal Prussia, since when he was a young man the future forger, Krzysztof Stanisław, entered the Franciscan monastery of Kalisz as a novice. This could be treated as evidence of a close relationship of part of the family with this region. ${ }^{34}$ According to A. Boniecki there was also one other relation of Bartłomiej, Jan Janikowski, who at about the same time was the owner of Komorowo near Lipno in the region of Dobrzyń. ${ }^{35}$ It was he that might have been a link between the branch of the family in the Kalisz voivodship and Sandomierz region and the one settled in the region of Skarszewy and Gdańsk in Royal Prussia and may have been a relation, and maybe even a close relative, of Krzysztof Stanisław. ${ }^{36}$

The father of the future forger, Stanisław, was probably the eldest of at least five presumed siblings, ${ }^{37}$ which can be identified on the basis of careful analysis of the documentary heritage of the Janikowski family. His presence in the Gdańsk region already in 1603 is documented by the written sources (see below). The first to reach maturity in the next generation of the Janikowski family was his oldest son, Jan Stanisław. The first of the uncles of Krzysztof Stanisław could have been Krzysztof (only once mentioned in 1622 as the representative of the widow and orphans of his murdered brother), ${ }^{38}$ after whom the subject of the present article inherited his first name. A little younger than Krzysztof was Andrzej (his son Paweł was already able to conduct legal actions independently by 1636$)^{39}$ who is only mentioned in written sources created in the 1620s (but without allowing closer dating), as the man who presented Jan Stanisław, the oldest of the heirs of the murdered Stanisław (see below), with two geldings. ${ }^{40}$ In June 1629 he was no longer alive. ${ }^{41}$ From the content of the above-mentioned ledger of Jan Stanisław Janikowski, the brother of the future forger, we learn that he lived in the neighbourhood of the Janikowskis of Łostowice, and perhaps even in Łostowice itself. ${ }^{42}$

${ }^{34}$ The Franciscan novitiate in Kalisz: J. Rumiński, Janikowski Krzysztof Stanisław, p. 518.

${ }^{35}$ A. Boniecki, op. cit., p. 190.

${ }^{36}$ The name Jan was frequently given to children in the family circles of the forger in the first half of the $17^{\text {th }}$ century.

${ }^{37}$ Due to the lack of direct information from the sources, it cannot be excluded that some of the above-mentioned people were however not brothers, but more distantly related cousins.

${ }^{38}$ APGd, document number 300, 52/951, p. 115. The fact that it was he who became the family's representative at this difficult time could be evidence for his presumed seniority.

${ }^{39}$ Ibid., document number 300, 52/950, pp. 37-38. Under the date 14 Oct. 1636.

${ }^{40}$ Ibid., document number 300, 52/948, "Memoriale debitorum..." p. 14. This note appears in the ledger kept by Jan Stanisław - the older brother of Krzysztof Stanisław - but unfortunately, without giving dates, but the note was made some time between 1620 and 1628 . The name Andrzej, given to the middle son of Stanisław born before Krzysztof Stanisław could even suggest that Andrzej was, however, older than Krzysztof.

${ }^{41}$ B.O., manuscript 3179 II, k. 189v. There was also listed in this document his daughter, Zofia.

${ }^{42}$ The oldest church registers for Łostowice date back to 1659, which of course makes it difficult to identify the immediate family of Krzysztof Stanisław. In the vicinity of Łostowice in the Jesuit church of the Visitation of the Blessed Virgin Mary in Stare Szkoty we note, however, under the date of $12^{\text {th }}$ May 1620 a pair of godparents named Andreas and Elisabetha Jankowski. Elisabetha Jankowska was again a godmother here in December 1616. See the Archiwum Archidiecezjalne w Oliwie 
The third uncle of Krzysztof Stanisław could have been Jan Stanisław, who appears in the surviving written sources quite late, for he only appears in May 1647 in correspondence between him and the forger when the latter was still $-\mathrm{a}$ few months before catastrophe and his death - an influential royal secretary. ${ }^{43}$ His seniority may be evidenced by his having two sons who were already adults already in the 1640s (that is Stanisław - accomplice of the forger, and Stanisław Jan - a hetman's courtier). The fourth presumed uncle had the name Wacław and left a son Marcjan who was a minor at the time of the death of his father (before $2^{\text {nd }}$ November 1636), but an adult collaborator in the creation of the forgeries of his cousin in the middle of the decade following this. ${ }^{44}$

For completeness, it is necessary to say something about the family of the forger's mother - Katarzyna, née Sobańska. The Sobański family used the Korczak arms and were, as emphasised by the armorial, Herbarz szlachty kaszubskiej minor nobility (owning only a fraction of a village) from the borderland between the districts of Kashubia and Kociewie, and coming from the village Sobącz near Nowy Barkoczyn.$^{45}$ Among the co-owners of that village in the first half of the $17^{\text {th }}$ century, the documents list a Zachariasz Sobański (1648), most probably the same Zachariasz Sobański who in 1625 was in the service of the nobleman Wojciech Młodawski, the heir to Karznice Małe (now Karsznice - part of Zduńska

[Archdiocesan Archives in Oliwa] (further cit. AAO), document number D 28 (Baptisms, no pagination). Is it mere coincidence of names, or do we see here an example of the tendency, quite frequent at that time, to omit a single letter in a name, which happened in regard to the members of this family, even in the scrupulously-kept Gdańsk Kämmereibuch (account records of the City Council)? If so, it would be so perhaps another trace of the habitation in the area of the Janikowskis.

${ }^{43}$ APGd, document number 300, 52/960, pp. 81-84. This letter, dated $2^{\text {nd }}$ May 1647 from Husiatyn in Podolia, Jan Stanisław Janikowski reverentially writes to Krzysztof Stanisław Janikowski and clearly names him nephew and grumbled at the same time about his health and age. He was there then alongside his younger son, Stanisław Jan, who through the intercession of the forger had obtained a position as the head chef in the court of Marcin Kalinowski, hetman of the Crown and the governor of Czernihów. From subsequent correspondence it transpires that Jan Stanisław was not satisfied with his position at court functions, and left the post, asking his cousin to obtain him a new, better job, see ibid., pp. 193-194. The oldest son of Jan Stanisław, also named Stanisław, was however at the side of the forger himself already in 1641 and faithfully served him in different - though also criminal - activities until his death in August 1647. For the record - with regard to Jan Stanisław Janikowski, the uncle, it should be added that in the above-cited register of the Jesuit church in Stare Szkoty under the date $3^{\text {rd }}$ February 1619 is reported that at the baptism of Pawel, the son of Anna and Stanisław Godniczs, the two godparents were Jan (Joannes) and Elizabeth (Elisabetha) Janikowski. However, maybe this in fact means the aforementioned Andrzej and Elżbieta Jankowski (then Jan would be Andrzej's second or first name). See AAO, document number D 28 (Baptisms).

${ }^{44}$ APGd, document number 300, 52/948, pp. 71-74. This is an inventory of the property after the death of Wacław. It does not however state the location of this property. See also: J. RumińsKI, Fałszerstwa, pp. 55-56.

${ }^{45}$ P. Pragert, op. cit., vol. 2, p. 180. 
Wola). ${ }^{46}$ The father of Katarzyna was named Szczepan. ${ }^{47}$ The history of the earlier generation of Katarzyna's ancestors, and name of other members of her family are unknown, nothing is known of her siblings, even though it must have been a very large family. By a strange coincidence, the wife of the above-mentioned Wackaw Janikowski was also a Katarzyna from the Sobański family ${ }^{48}$ but she was certainly not the mother of the forger.

\section{STANISŁAW JANIKOWSKI - THE FORGER'S FATHER}

On $9^{\text {th }}$ June 1603 a transaction was concluded between the noblemen Ernest Krokowski and Stanisław Janikowski before the lay court in Puck. The object of the transaction was the sale of 9 włókas of land in Łostowice near Gdańsk with all the privileges that went with it. Ernest, a royal courtier, a member of the Sejm of the Rzeczpospolita and later a lay judge of the regional court o Puck was since 1602 the main heir to the Krokowa estate, son of Reinhold (who died in 1599 - he had been a Condottiere in the service of the Hugenots during the religious wars in France) and Barbara (née Wejher of Krokowa). His high position in the nobility was indicated by the use in the documents concerning the transaction of the term "generosus." ${ }^{49}$ The above-mentioned property was sold in his own name jointly with his mother and brother Jerzy. Stanisław Janikowski - who figures in the document only as "noble" - became the owner of the land ${ }^{50}$ together with all the rights and privileges. On the basis of a leasing contract issued a dozen years later ( $8^{\text {th }}$ July 1616), in Buszkowy near Gdańsk, it can be concluded that S. Janikowski sought to expand the scope of his possession in Łostowice. This document, somewhat obscurely-phrased, states that for the last two years, Janikowski been a subtenant of Paweł Arciszewski, the heir to Buszkowy near Gdańsk, ${ }^{51}$ of a further property in Lostowice, belonging to the Winters, ${ }^{52}$ and the latter rented it under "a certain con-

${ }^{46}$ Ibid. See also: Jacek Kowalkowsкi, Wiesław Nowosad, Testamenty szlachty Prus Królewskich z XVII wieku, Warszawa 2013, p. 118.

${ }^{47}$ APGd, document number 300, 52/948, p. 13.

${ }^{48}$ See footnote 50 .

${ }^{49}$ On the Krokowskis see among others: P. Pragert, op.cit., vol. 4, pp. 140-141. Moreover: Maria SŁawoszewsKa, Krokow Reinhold von (1536-1599), [in:] PSB, vol. 15, Wrocław 1970, pp. 316317; eadem, Krokowski Ernest (1575-1631), [in:] ibid., pp. 317-318. See also: Urzędnicy Prus Królewskich, pp. 149-150. Contract: APGd, document number 519/46, k. 119v-121.

${ }^{50}$ On the basis of the older contract of 1574 between Barbara née Weher from Krokowo and the burgher Gregor Lüdke we may conclude that this referred to the portion of Łostowice bordering on Ujeścisko (APGd, document number 519/46, k. 120v).

${ }^{51}$ Ibid., document number 300, 52/948, p. 1. Paweł Arciszewski, the heir to Buszkowy, an Arian, was about 1623 Chamberlain at the court of Anna Vasa in Brodnica and a distant relative of Krzysztof Arciszewski, Dutch admiral and royal general of the royal army. See J. K. DACHNowsKi, op. cit., p. 215; Maria ParadowsKa, Krzysztof Arciszewski. „Przyjmij laur zwycięski”, Katowice 1987, pp. 7-8, 11-12.

${ }^{52}$ The von Winter family, later known from the Gdańsk region came from Royal Prussia, but gained significance in Gdańsk only in the second half of the $17^{\text {th }}$ century (Colonel Valentin von 
tract" from Jacob Sieniński. ${ }^{53}$ Jacob Sieniński in turn had sublet the land to P. Arciszewski (which, however, is not clearly stated in the document). At any rate, the document states that "in the end" the property was leased to Stanisław Janikowski (as confirmed by the entry to the municipal records of Skarszewy) and now Arciszewski confirmed this, the second year of the lease, taking from S. Janikowski 165 Polish zlotys extending his sublet for a further five years. ${ }^{54}$

A few years later, in 1619, the city council - perhaps under the pressure of one of the patrician families of Gdańsk interested in buying this property - intervened in order to settle the issue of the ownership of Łostowice and bought this "der Winterische Theil" from P. Arciszewski, taking into account the settlement of the compensation for rights and claims of S. Janikowski. In exchange for giving up the lease, he obtained 200 zlotys (300 grywnas), and the total redemption amount - paid from the city treasury and delivered to both interested parties by the Municipal Secretary, Philip Lacke (Lacken, Lakken) ${ }^{55}$ amounted to the equivalent of 988 grywnas. ${ }^{56}$ Philip Lacke was to send the money to Skarszewy on $2^{\text {nd }}$ August and the receipt of the funds was recoded in the municipal records there according to the information contained in the books of the kämmerei. ${ }^{57}$ There remained however the matter of the land that the Janikowskis had inherited in this village. From two further inscriptions in the kämmerbuch (21 $1^{\text {st }}$ October 1619 and $19^{\text {th }}$ February 1620$)^{58}$ it transpires that Stanisław Janikowski conferred his rights to part of Łostowice to two other noblemen, Pudevels ${ }^{59}$ and Jerzy

Winter was the commander of the garrison of Gdańsk during the Swedish "deluge" in the years 1655-1660). Certainly, it was thus a different branch of the family. In Gdańsk, in the years 1625-1633 property records mention an Anna, the widow of Andres Winter, and also their sons - Dawid and Samuel (see APGd, document number 300,32/4, k. 54). They had a tenement house at 14, Tkacka street near the Pusch house which the Janikowskis later appropriated. Members of the Winter family are mentioned in the registers of Gdańsk churches (eg. in the parish of St. Catherine).

${ }^{53}$ According to K. Niesiecki (K. NiesıeCKI, op. cit., vol. 8, p. 354), the Sieniński or Sienieński family was derived mainly from Red Ruthenia and there is no record of it in Prussia in any of the armorials cited here. It is known, however, that in 1591, Krzysztof Sieniński (the heir to the property at Kotomierz in the district of Bydgoszcz in the Krajna region, bordering on Royal Prussia) married Katarzyna Wałdowska. Perhaps Jakub was his close relative. See J. Kowalkowski, W. Nowosad, op.cit., p. 82.

${ }^{54}$ APGd, document number 300, 52/948, pp. 1-2.

${ }^{55}$ Philip Lacke (1576-1640), was secretary of the council in the years 1601-1629, then went into the service of the king. According to the critical remarks of Arthur Methner, while serving the Polish monarchs, he "seriously harmed the interests of the city". See Arthur Methner, Die Danziger Stadtschreiber bis 1650, Danziger familiengeschichtliche Beiträge, H. 2, Danzig 1934, p. 35.

${ }^{56}$ APGd, document number 300, 12/49, p. 119.

${ }^{57}$ Ibid., p. 129. Philip Lacke obtained expenses for this journey of 18 zlotys and 10 groschen.

${ }^{58}$ Ibid., pp. 289, 307.

${ }^{59}$ Maybe this refers to Georg Pudevels, mentioned in J. K. Dachnowski's armorial as a nobleman from Krajna (since he sent messengers to Tuchola!), whose ensign - epitafium was to be found "in the parish church" (in other words, the Church of the BVM?) after 1626. See J. K. DACHNowsKI, op. cit., p. 238. 
Jackowski. ${ }^{60}$ The city tried to obtain this land also, but this matter remained unresolved until the end of Janikowski's life.

In the same year (1620) perhaps in the hope of obtaining cash from the treasury of Gdańsk, Stanisław purchased from Jan Stanisławski and his wife Zofia (Justyna - née Szorc), the heirs of Boroszewko near Godziszewo, ${ }^{61}$ a small village called Pawłowo, located a few kilometers north of Skarszewy (considered together with Skarszewy to belong to Tczew county - hence the later belief that the Janikowskis were nobility from the Tczew region). This took place in two stages, on $14^{\text {th }}$ February 1620, in the presence of Hektor Czarliński, lay judge of the regional court of Tczew, ${ }^{62}$ (the legal guardian and plenipotentiary of Zofia), Stanisław Janikowski concluded with the Stanisławskis a preliminary agreement (later confirmed by being inscribed into the records of the regional court of Starogard under the date of $11^{\text {th }}$ March) on the purchase of that village, together with all the rights that went with it for the sum of 10000 zlotys. ${ }^{63}$ Stanisław Janikowski agreed to pay a deposit of 2000 zlotys before $14^{\text {th }}$ February, 1620. A further thousand was to be paid before the $14^{\text {th }}$ March of that year. Because earlier the Stanisławskis had "signedover" Pawłowo as a "security" (probably some kind of Wiederkauf arrangement) to Stefan and Anna Elżanowski, ${ }^{64}$ Janikowski undertook to convey to them the amount of 5000 zlotys four weeks before the completion of the agreement with the Stanisławskis. The last two thousand were to be paid only after two years counted from the feast of St. John 1620 (that is by $24^{\text {th }}$ June, 1622). Until the final settlement with the Stanisławskis (and Elżanowskis), Janikowski had to permit the collection of wood from the place known as "porębisko" in the forest of Pawłowo for the needs of the Stanisławski property in Boroszewo. ${ }^{65}$ The actual sales contract

${ }^{60}$ In the above-mentioned records of Jackowski he is in fact left nameless, but from the evidence given following the murder of Stanisław Janikowski, it is known that his name was Jerzy and he was born in 1583 (see APGd, document number 300, 52/948, p. 3). He is not mentioned in the armorial of J. K. Dachnowski (see J. K. DAChNowsKi, op. cit., p. 167), and P. Pragert's armorial only lists a Jerzy Jackowski who was a lay judge of the Tczew court, who died in 1594 (see P. Pragert, op.cit., vol. 1, p. 85). Maybe the Jerzy Jackowski known from the Kämmereibuch was the son of the latter.

${ }^{61}$ The Stanisławskis of the Sulima coat of arms came from Stanisławie near Tczew. See J. K. DACHNOWski, op. cit., p. 227.

${ }^{62}$ See Urzędnicy Prus Królewskich, p. 160.

${ }^{63}$ APGd, document number 300, 52/949, pp. 1-4. Inscribed into the records of the regional court of Starogard $11^{\text {th }}$ March 1620.

${ }^{64}$ Stefan Elżanowski was the brother of Łukasz Elżanowski, ensign, and then Castellan of Chełmno (who died in 1637. - See Urzędnicy Prus Królewskich, p. 55). He came from the province of Chełmno and up to about 1606 was the owner of part of the village Pruska Łąka. According to Bartosz Drzewiecki in 1609 his name disappeared from the written sources of this region. Bartosz Drzewiecki suggests that he took part in the expedition to Moscow in 1610 and did not return from it, pp. 111, 146). However, according to the sources on the dispute discussed here, he was still alive at least in 1620. Anna (née Stanisławska - see Bartosz Drzewiecki, Szlachta województwa chełmińskiego w latach 1545-1772. Mobilność społeczna i terytorialna, Warszawa 2014, p. 110), his wife, was probably the sister of Jan Stanisławski.

${ }^{65}$ APGd, document number 300, 52/951, pp. 116-118. 
was drawn up on $14^{\text {th }}$ August, 1620 and inscribed into the records of the regional court in Tuchola. ${ }^{66}$ This document confirmed all the previous arrangements, particularly as to the total amount of payment and the transfer of assets with all its real estate and movables, privileges and records, at the same time, however, it contained a new clause excluding from the sale the part of Pawłowo called separately "Porębiska," which had belonged to Stefan and Anna (née Stanisławska) Elżanowski. Perhaps this "Porębiska" (land with the right to logging?) was to compensate Elżanowski for some deficiencies in the payment of the amount due, and that he therefore felt he had been deceived by Janikowski. Some time between $14^{\text {th }}$ and $28^{\text {th }}$ August, 1620, a meeting took place in Starogard between Stanisław Janikowski and Stefan Elżanowski, during which the latter unexpectedly drew his gun and shot his unsuspecting partner. The testimony that more than two months later, on November $4^{\text {th }}, 1620$ the witnesses of this incident made before the regional court of Starogard was somewhat unclear and, above all, they did not indicate any reason for which there this crime took place. Everyone unanimously emphasized that both nobles previously had very proper, even friendly, relations ${ }^{67}$ In the light of the accounts kept by the son, Jan Stanisław Janikowski, Stanisław did not die right away, his relatives tried to save him, they called the barber, then a priest. ${ }^{68}$ The oldest of the sons of the murdered man, Jan Stanisław, then undertook legal steps to have the killer punished. Stefan Elżanowski tried to save himself from punishment and in order to achieve this had been trying to show that the Janikowskis were of lowly (plebian) origins. For the purpose of counteracting these claims, Jan Stanisław went to Opoczno, and then spent five weeks in the nearby Piotrków, probably trying to obtain justice before the local Tribunal. ${ }^{69}$ Only after these moves did he return to Starogard and hold a funeral for his father. ${ }^{70}$ Stefan Elżanowski was sentenced with an 'infamia' by the Tuchola court. ${ }^{71}$

\section{THE OLDEST BROTHER - LAY JUDGE OF TCZEW, MEMBER OF THE SEJM AND DEPUTANT JAN STANISŁAW JANIKOWSKI}

Certainly the eldest of the brothers, Jan Stanisław Janikowski, had a much greater impact on fate and moral choices of the future forger. It was at his side that in effect Krzysztof Stanisław entered the adult world. Shortly after the death of his

${ }^{66}$ Ibid., document number 300, 52/949, pp. 5-8.

${ }^{67}$ Ibid., document number 300, 52/948, "Depositio testimoniorum," pp. 3-6. One witness, Jan Stanisławski, the main party interested in arbitration settling the case and probably the brotherin-law of the killer, even claimed that it was not Elżanowski who killed the man, but his servant, named Wiecki. In turn, the "hard-working" John, the coachman of Jerzy Jackowski (also a witness of the murder), testified that at the time Elżanowski shot Janikowski, he had screamed "you son of a whore!"

${ }^{68}$ APGd, document number 300, 52/948, "Memoriale debitorum...," p. 9.

${ }^{69}$ Ibid.

${ }^{70}$ Ibid., pp. 9-10.

${ }^{71}$ Ibid., p. 10. 
father, Jan Stanisław began to keep a ledger, with the date $28^{\text {th }}$ August, 1620 on the title page. ${ }^{72}$ The entries were written in Polish, but in accordance with the trends of the time he added many phrases in Latin that indicate that he knew this language quite well. His use of spelling indicates moreover a certain degree of knowledge of German, or at least Neo-Gothic mannerisms. The petitions which he rather frequently addressed to the city council in Gdańsk were, however, always written in Polish. He continued his legal case against S. Elżanowski in the courts of Starogard, Tuchola and Piotrków, through successive types of legal procedures, and also hiring a plenipotentiary, a certain Starczewski, ${ }^{73}$ to appear before these courts. This testifies not only about the feeling of injustice he felt, but about his awareness of the justice that applied to the nobility and his feeling of entitlement to make use of it. After the war in 1626 to 1629 Jan Stanisław Janikowski attributed to himself the rank of an officer. It is however not at all clear that he actually was a soldier. From his account book, it does not appear that he served in the army during - for example - the Chocim campaign or in other armed conflicts of that time.

Jan Stanisław spent much of the first year after Stanisław's death on the establishment of his rights to his father's inheritance, the judicial prosecution of the killer and disputes with his own mother. ${ }^{74}$ Before an agreement was reached over Pawłowo, it was known that he rented Postołowo, the property of the voivode of Chełmno, which would testify to his good relationship with the Wejher family. ${ }^{75}$ The problems with Pawłowo stemmed from unresolyed issues from the times of his father concerning the payment of some instalments of the price of the property. Jan Stanisław several times had to ride because of this to Skarszewy, as mentioned in his ledger. The context of the surviving documents clearly suggests that in the first months after the murder of Stanisław Janikowski, Pawłowo was in the hands of the Elżanowskis, who were not only looking after their "porębisko," but also awaiting the return of the debt, the amount of the pledge that was owed to them. Anna Elżanowska lived in Pawłowo, perhaps in order to guard the interests of the family in the place of her fugitive husband. After her unexpected death (in the first half of 1621?), Jan Stanisław Janikowski hired 12 "knechts" and with four of his own servants forcibly occupied Pawłowo, and the armed occupation of this property lasted (as he wrote in his account book) 13 weeks. ${ }^{76}$ In fear of being attacked by the Elżanowskis, he hired an additional three men and "bought gunpowder and lead." ${ }^{\prime 7}$ At the same time, with the help of the above-mentioned Hektor

${ }^{72}$ Ibid., p. 7.

${ }^{73}$ Ibid., p. 10.

${ }^{74}$ Ibid., p. 11. The account book is the only written source to inform us of the conflict with the mother, but it does not enlighten us as to the reason for it.

${ }^{75}$ Ibid. Postołowo is a village lying north of Skarszewy, its lands bordering with Pawłowo. The voivode of Chełmno was then Jan Jakub Wejher, and his wife Anna (née Szczawińska).

${ }^{76}$ If we assume that the "occupation" ended with the formal agreement with the Stanisławskis, that is the beginning of September 1621, the raid could have occurred in late May and early June 1621.

${ }^{77}$ APGd, document number 300, 52/948, "Memoriale debitorum...," p. 11. 
Czarliński, there was a temporary respite in the conflict between the Janikowskis and the Stanisławskis. ${ }^{78}$ As stated in the Gdańsk Kämmereibuch of $4^{\text {th }}$ September 1621, Janikowski in respect to his claims to the ownership of part of Łostowice (at this point the value was estimated - according to him - as 7000 Prussian grywnas) received from the municipal treasury the amount of 500 zlotys (750 grywnas) ${ }^{79}$ thus, a modest portion of the expected profits. The same day, in a document entered into the records of the lay court of the Old Town of Gdańsk, the Stanisławskis confirmed that they had obtained from Katarzyna (née Sobańska), widow of Stanisław and Jan "Stanczik" Janikowski the amount of 6000 Polish zlotys, as the rest of the amount due for Pawłowo and therefore confirmed that the Janikowskis now owned the property "for ever."

Again on the same day came a record of a loan 620 zlotys given to the whole Janikowski family (the widow of the murdered Stanisław and her sons and daughters) by the city council of Gdańsk with Pawłowo being the security. The loan was to be repaid by $29^{\text {th }}$ September (St. Michael's Day) the next year, and if there was default, the city would take the property. ${ }^{81}$ Considerably later, the legal acts were drawn up (the original document, issued in Gdańsk on $13^{\text {th }}$ June, 1633) suggested that in fact the lender was the then mayor of Gdańsk, Arnold von Holten..$^{82} \mathrm{~A}$ few days after the conclusion of the agreement on Pawłowo (1 $1^{\text {th }}$ September, 1621), assurance of the loan was obtained. Jan Stanisław received 300 Polish zlotys from the city treasury, guaranteed by the mortgage of Pawłowo and with the appropriate rent applied. The money was to be returned by $29^{\text {th }}$ September of the following year. ${ }^{83}$ The comparison of the amounts gained and borrowed with the size of the liabilities to the Stanisławskis (not to mention the Elżanowskis) suggest that the Janikowski family still had not sorted out the legal situation with Pawłowo and had

${ }^{78}$ Ibid.

${ }^{79}$ Ibid., document number 300, 12/52, p. 161.

${ }^{80}$ Ibid., document number 300,52/949, pp. 13-16. The lack of the records of the lay court of the Old Town for this period renders it impossible to verify this document. It is known however that Jan Stanisław Janikowski wrote in his ledger book that he was in Gdańsk with his friend (Czarliński?), mother and servant.

${ }^{81}$ Ibid., pp. 17-20. This record of the debt is a notarized copy of the document entered September $13^{\text {th }}, 1621$ into the records of the regional court in Starogard, and a repeat of the relevant content from September $4^{\text {th }}$, recorded in records of the lay court in the Old Town of Gdańsk. Janikowski obtained a copy of this in Starogard on April 27 $7^{\text {th }}, 1631$. In his accounts Jan Stanisław Janikowski noted, however, that the debt "to the town hall" for the "repeal of the Szenfalt rent" and borrowed money totalled 950 Polish zlotys (see APGd, document number 300, 52/948, "Memoriale debitorum...," p. 16). Janikowski's muddled bookkeeping meant that he entered the same sum in another place, giving exactly the same amount of 950 Polish zlotys as having been obtained "from the men of Gdańsk as a loan" in the category "percepta," that is income.

${ }^{82}$ APGd, document number 300, 52/948, pp. 63, 65.

${ }^{83}$ Ibid., document number 300, 12/52, p. 169. It therefore remains unexplained whether for unknown reasons J. S. Janikowski was given less than was promised in the original loan agreement, or - whether this was further money from the city. In the Kämmereibuch there is no trace of the payment of 620 florins. These, however, could have come from the private pocket of von Holten. 
not satisfied the creditors' claims. Not surprisingly, they continued to submit their own claims to the land in Łostowice. The effect of the assumed protestations of Jan Stanisław Janikowski were further legal costs recorded in the Gdańsk Kämmereibuch, including the so-called "(re)protestation" undertaken by the municipal official (Simon Kraczinski also known as Kruczinski) in the courts in Tczew (!), Skarszewy and Starogard (October 1621) ${ }^{84}$ Among the costs then incurred there was also a mention of a mysterious "autopsy" in Zaroślak (Petershagen), a suburban property of Gdańsk. Maybe this is connected with the enigmatic note in Janikowski's accounts book about "dealing with" Elżanowski. Jan Stanisław Janikowski also paid for the 21 barrels of beer, which the henchmen ("from Łaguszewo, Skarszewy and Sobowidz"), hired by him had drunk; together this phase of the war with Elżanowski had cost him more than 200 zlotys. ${ }^{85}$ After all this, as stated in the accounting book, he finally settled in ravaged Pawłowo and started to farm there, but the costs incurred (according to him amounting to more than 600 Polish zlotys), were not recovered because of a severe winter and crop failures and required further cash outlay from him. ${ }^{86}$ Certainly, further problems were also associated with the still unsolved matter of claims of Janikowski to Lostowice (a lawsuit served by the city in Pawłowo on June 1, 1622, another - June $25^{\text {th }}$ the same year). ${ }^{87}$ Demanding payment of the obligation on the part of the city on $16^{\text {th }}$ September, 1622, Jan Stanisław at the same time submitted a fairly humble petition to the city council of Gdańsk for an extension of the term of the loan and the transfer of the commitment to repay it for another year. The council agreed to this request. ${ }^{88}$ There was eventually success in the conclusion of a final settlement on the matter of Pawłowo between the Stanisławskis and the whole Janikowski family represented by Jan Stanisław. Its price was the commitment of the latter on behalf of the mother and siblings to a refund of the deposit-loan to the amount of 1000 Polish zlotys (document of $14^{\text {th }}$ November, 1623, recorded in the records of the regional court of Starogard). ${ }^{89}$

The person who gave the most help to Janikowski to allow him to exit from a difficult situation was the city secretary, Philipp Lacke already mentioned above. Lacke had at that time a property at Ełganowo, bordering on Pawłowo and in relation to the above-mentioned problems with crop failures helped his neighbour with the amount of 344 florins and 15 groschen, "For the needs of the manor." 90 Jan Stanisław Janikowski (in a document of June 27, 1624) pawned all of Pawłowo

${ }^{84}$ Ibid., document number 300, 12/52, p. 217.

${ }^{85}$ Ibid., document number 300, 52/948, "Memoriale debitorum...," p. 12.

${ }^{86}$ Ibid.

${ }^{87}$ Ibid., document number 300, 12/53, p. 151.

${ }^{88}$ Ibid., document number 300, 52/948, pp. 19-20.

${ }^{89}$ Ibid., document number 300, 52/949, pp. 21-22.

${ }^{90}$ Ibid., document number 300, 52/948, "Memoriale debitorum...," p. 12. There is no date given, but we can deduce from the order in which entries were made in J. S. Janikowski's accounting books that this occurred some time after in the winter of 1622 to 1623. 
to this same Philipp Lacke for the not inconsiderable amount of 9600 Polish zlotys (with a very short period of redemption, to Easter 1625). ${ }^{91}$ Certainly, thanks to this injection of monetary capital, Janikowski could pay off - temporarily - all his "debts of the corpse," including settle the lease agreements of Łostowice with Paul Arciszewski, pay all of the above mentioned arrears to the Stanisławski and several other creditors of his father. In total, these commitments cost him 5559 florins and 17 groschen. $^{92}$

One can only guess that the pledge (actually a typical wyderkaf) only temporarily improved the situation of the Janikowskis, and Jan Stanisław became dependent on the Gdańsk secretary. On $30^{\text {th }}$ December 1625, Philipp Lacke shed his lien with respect to Pawłowo to the infamous Jacob Pusch (Pusz), citizen and merchant of Gdańsk, and his wife, Barbara (née Olrychsen). Pusch paid at the same time for himself (3200 Polish zlotys), as well as covering Janikowski's debts (to the sum of 2600 Polish zlotys). ${ }^{93}$ In this way, Jan Stanisław Janikowski tied his fate with that of the Pusch family, first in the economic sense, but later in terms of blood relationships.

Very little is known about the Pusch family. They had property in the middle of the Main Town of Gdańsk, on Tkacka street (later this plot was numbered 6 Tkacka street). In October 1632, Jacob, son of the above-mentioned Jacob and Barbara, had run up a debt on this tenement to the amount of 218 florins and 18 groschen. ${ }^{94} \mathrm{He}$ was therefore already an adult, and thus at this time his mother was an older woman. In turn, in his testament prepared by the younger Jacob on $3^{\text {rd }}$ June, 1654, he speaks of his heirs: his "dear brother" Mark (Marcus Pusch), ${ }^{95}$ the children of his "beloved brother-in-law," Daniel Jencken and of Hans Gregens, the son of a second brother-in-law (also named Hans Gregens) to whom Jacob Pusch left his books on theology and philosophy, with an encouragement to study them. ${ }^{96}$ He must, therefore, have been a wealthy and educated man.

On $21^{\text {st }}$ June 1627, Jan Stanisław, the "lord of Pawłowo" concluded a contract with the "noble" Philipp Lacke, in which it is stated that Janikowski had inherited liabilities to the amount of 3200 zlotys after the death of Jacob Pusch and entering his name on the mortgage on Pusch's house on Tkacka Street in Gdańsk. From this

${ }^{91}$ Ibid., document number 300, 52/949, pp. 25-28 (entered into the records of the regional court of Skarszewy).

${ }^{92}$ Ibid., document number 300, 52/948, "Memoriale debitorum...," p. 13.

${ }^{93}$ Ibid.; document number 300, 52/949, p. 41. In other documents connected with "the Janikowski Matter," this inhabitant of Gdańsk is denoted as "noble" and given the name "Pusch a Gemssen" or "Gembsen". See ibid., document number 300, 52/948, "Memoriale debitorum...," p. 7.

${ }^{94} \mathrm{Ibid}$., document number $300,32 / 4, \mathrm{k}$. 55. The debt was encumbered with interest of $7 \%$, and was to be repaid on St Michael's Day 1633.

${ }^{95}$ In June 1616, Rudolphus and Marcus Pusch began studies at the Academic Gymnasium in Gdańsk. It is unknown how old they were. Was therefore Rudolf one of the brothers of Jacob? See Księga wpisów uczniów Gimnazjum Gdańskiego 1580-1814, edited by Zbigniew NowaK, Przemysław Szafran, Warszawa-Poznań 1974, p. 100.

${ }^{96}$ APGd, document number 300, 43/56, k. 194v-195v. 
agreement, somewhat confusingly formulated, it appears that between December 1625 and September 1627 (and probably already before $9^{\text {th }}$ August 1626 - see below), not only had Jacob Pusch senior died, but Janikowski had married his above mentioned widow, Barbara. This marriage was probably for Jan Stanisław not so much a noble gesture to "rescue" the widow, as much as a way of extrication himself from the loop of his own debts. The marriage remained childless. The rent of the house of $7 \%$ was intended to support the debt that had to Lacke. ${ }^{97} \mathrm{He}$ also rented Pawłowo for three years to another Gdańsk resident, the merchant Peter Eggert in return for an immediate loan of 3000 zlotys, in effect relinquishing to the latter for the entire period of the contract nearly all his prerogatives in that village. ${ }^{98}$ According to the wording of the records in the above-mentioned "Memorial debitorum...," unfortunately again without dates, the money was needed most likely in connection with further huge expenditure of the nobleman. About the same time as the above mentioned contracts were drawn up, Jan Stanisław paid his mother (2000 zlotys) and married off his two younger sisters, offering each 1000 zlotys in cash and a further 500 zlotys in property and domestic equipment. Holding the two wedding parties was to cost him a further 520 zlotys. ${ }^{99}$ The middle sister, Barbara, married Łukasz Rowiński. ${ }^{100}$ The youngest sister, Elżbieta, married Jan Stanisławski, the above-mentioned heir to Boroszewko and debtor of the Janikowskis, maybe this was one of the methods by which the conflict between the Janikowski family and the former owners of Pawłowo were to be resolved. ${ }^{101}$ At the end of these costs, Jan Stanisław Janikowski stated in his accounts book that the upkeep of Pawłowo (and therefore the cost of maintaining his status as a landowner possessing a whole village), including the cost of continual recovery of pawned properties, had cost him more than 20000 zlotys. ${ }^{102}$

The account book of Jan Stanisław Janikowski do not even once make any mention of military spending, while participation in the "War of the Mouth of the Vistula River," started in July 1626 by the invasion of Swedish troops in Pilau in the Duchy of Prussia played no small role in his life and personal career. The armorial of Jan Karol Dachnowski summarises this role with obvious appreciation, stating

${ }^{97}$ Ibid., document number 300, 52/948, pp. 35-38.

${ }^{98}$ Ibid., pp. 43-46.

${ }^{99}$ Ibid., "Memoriale debitorum...," p. 15.

${ }^{100} \mathrm{~A}$ member of the aristocracy not listed in the available armorials and studies of this area.

${ }^{101}$ APGd, document number 300, 52/948, pp. 69-70. For completeness it should be added that Katarzyna Janikowska (née Sobańska) died in 1631 and in 1633 two of her sisters (the oldest Dorota and youngest Elżbieta) were also dead. Before 1641, Barbara, was widowed and married Grzegorz Tokarski, another of the collaborators with Krzysztof Stanisław in his forgeries and violent actions, see ibid., document number 300, 52/951, p. 71.

${ }^{102}$ Ibid., document number 300, 52/948, "Memoriale debitorum...," p. 15. Lacke and Eggert were not the only people to give Janikowski credit in this time. On 18th January 1626, Jan Stanisław gave Jani Niczki (Nicki) a "handwritten receipt" for 800 zlotys. The existence of this family in Royal Prussia is confirmed - somewhat enigmatically - J. K. DACHNOWSKI, op. cit., p. 421. 
that as "Captain of His Majesty he gained great fame in the Prussian expedition." ${ }^{103}$ Settled in a camp near Tczew, the Swedish troops threatened Gdańsk, with the result that the city government had already started negotiations on July 16 with Gustav Adolf, the Swedish king. The latter wanted to force Gdańsk to declare neutrality, and its troops entered the territory of the city, occupying, among others, the Danziger Haupt fortress. ${ }^{104}$ At a critical moment of the negotiations, there was an incident involving Jan Stanisław Janikowski, who captured a Swedish captain at Gęsia Karczma near Gdańsk, ${ }^{105}$ and on $9^{\text {th }}$ August, escaping the squad of Swedish soldiers pursuing him because of it, he brought him into the town across the newly built New Bridge (Nizinna Gate) probably intending to take him to the Pusch house. Then the mayor Arnold von Holten (the same one that was behind the loan granted to J. S. Janikowski in September 1621) sent a squad of soldiers (in his later complaint J.S. Janikowski appears to have significantly exaggerated the number of 500 infantry with 4 cannons) and ordered him to free the prisoner and to hand over all the letters that he was carrying, and which - according J. S. Janikowski king Zygmunt III would learn of "a lot of practices and treachery" against him. ${ }^{106}$ Jan Stanisław Janikowski complained in a document entered nine days later into the records of the wojt's court of Grudziądz, that as a result of this seizure he was injured, lost not only a prisoner, but all the valuables that he had with him, including 800 red zlotys in cash, gold chains, rings, a cross and a pair of diamond earrings (which he had stolen from the Swede?). A few years later the royal lawsuit entered into the records of the municipal court of Skarszewy inform us that the Swedish officer had been carefully looked after in the house of von Holten and, having been accorded proper honours, was then sent back to the Swedish camp. Meanwhile, the injured J. S. Janikowski took refuge in "his house" in the city, ${ }^{107}$ but here too he was threatened by another troop of the army, this time numbering 400 soldiers. The soldiers stormed into the house, ransacked all the rooms from the basement to the attic, together with the chimneys, they searched cupboards and chests and took a number of valuable things, including pistols, carpets, a hat and "black coat." Jan Stanisław Janikowski was for a time imprisoned under house arrest there and threatened (if he complained?) with the looting and burning of Pawłowo. ${ }^{108}$

${ }^{103}$ Ibid., op. cit., p. 327.

${ }^{104}$ Władysław CzAPLIŃski, Zatarg z Batorym - stosunek Gdańska do planów Zygmunta III, [in:] Historia Gdańska, vol. 2: 1454-1655, edited by Edmund CieśLAK, Gdańsk 1982, pp. 607-611.

${ }^{105}$ APGd, document number 300, 52/949, p. 70. The Swedish officer was apparently heading for further negotiations with the Gdańsk authorities and stopped at the local tavern. It is not known whether it was by coincidence or deliberate counter-intelligence that J. S. Janikowski found out about it.

${ }^{106}$ APGd, document number 300, 52/949, pp. 49, 70.

${ }^{107}$ As can be seen, J. S. Janikowski treated the house as his property, but the property records of the Main Town of Gdańsk preserved from this period does not confirm such a position was justifed. The above-mentioned stepson, Jacob Pusch junior, had at that time the sole rights to this property.

${ }^{108}$ APGd, document number 300, 52/949, pp. 50, 71. The above-quoted copy of the documents from the archives of Grudziądz indicates that already nine days after that incident, on August 18, J. S. Janikowski was in Grudziądz, so the period he was under arrest did not last long. 
Janikowski complained, however, first in Grudziądz, that is, in the vicinity of the royal army of king Zygmunt III, and then brought the case, among others, before the Crown Tribunal in Lublin (August 1627, the lawsuit being retried in March 1631), demanding a very high compensation for losses to the amount of 17000 Polish zlotys! ${ }^{109}$ Representatives of the city claimed in their response to the complaint $\left(17^{\text {th }}\right.$ July, 1627), filed in the records of the wojt's court of Grudziądz that the allegations of J. S. Janikowski were unfounded. Nevertheless, J. S. Janikowski's version of events was supported by the lawsuits in the king's name (issued on $15^{\text {th }}$ and $17^{\text {th }}$ January, 1629 and entered in the records of the municipal court of Skarszewy dated January 30,1629), requiring Arnold von Holten to make amends for the damage suffered by Janikowski (the above-mentioned amount of money was to be secured on the property of von Holten in Mokry Dwór), ${ }^{110}$ and along with it the condemnation of the 17 other Gdańsk citizens who were "collaborators" of the mayor, most probably involved in the search and house arrest on Tkacka street. ${ }^{111}$ Mayor Arnold von Holten did not leave this unchallenged and the next day (31 January, 1629) he lodged in Skarszewy an appeal in the name of the city. ${ }^{112}$ The following year, the city authorities began a counter-action even more painful for Janikowski, demanding that the court in Skarszewy order the immediate repayment of the debt to the town treasury that the Janikowski family had incurred in September $1621 .{ }^{113}$ In the end, J.S. Janikowski did not receive his compensation, and the debt to the amount of 620 zlotys was paid off a few years later on behalf of his entire family into the hands of the Secretary of Gdańsk George Boy (the proxy of the heirs of mayor von Holten), as confirmed by a document of $13^{\text {th }}$ June $1633 .{ }^{114}$ At the end of July 1633 he was paid 60 zlotys from the funds of the Kämmerei (as reimbursement for the court costs). ${ }^{115}$

What was the actual significance of the incident with the Swedish officer and what role did J. S. Janikowski play in this affair? Was he working on his own, trying to hurt the city (with which he very clearly was still in conflict over the payment of some outstanding amount and unpaid obligations), or was he doing some task commissioned by the Polish monarch and his entourage? It is known that three

${ }^{109}$ APGd, document number 300, 52/954, pp. 1-8. We may presume that this money was also intended as recompensation for the loss of the rights to Lostowice.

${ }^{110}$ Ibid., document number 300, 52/949, pp. 77-78. The document confirming the "arrest" of this sum, issued on $22^{\text {nd }}$ March 1628 indicates that this might refer to the usual amount of the annual income from this property.

${ }^{111}$ Ibid., pp. 70-71, 73-74. The collaborators of Mayor von Holten were: Michael Schumann, Johann Koch, Joachim Holtennagel, Henricus Moller, Adam Sirach, Johann Möllerknab, Johann Puschmann, Simon Slew, Salomon Möller, Michael Reylenger, Georgius Polkau, Johann Winter, Ernst Schachmann, Christoph Henrichsen, Peter Schedler, Johann Stechel, Carol Kroll.

${ }^{112}$ APGd, document number 300, 12/58, p. 96.

${ }^{113}$ Ibid., document number 300, 52/949, p. 81. Document of $22^{\text {nd }}$ November, 1630.

${ }^{114}$ Ibid., document number 300, 52/948, p. 65. See also: ibid., document number 300, 52/949, pp. $85-88$.

${ }^{115}$ Ibid., document number 300, 12/67, p. 41. 
days after the action on the road near Gdańsk and the storming of the Janikowski house, the city council gave the Swedes an answer - despite some reservations of residents - which was considered a declaration of hostility and indicating the breaking off of negotiations. ${ }^{116}$ In the end, there was no direct attack by the Swedish army. Another interesting fact is that in none of the documents cited above from the times of the war of 1626-1629 is Jan Stanisław given the rank of any kind of officer, and he appears only for the first time as a captain (rotmistrz) in a document from March 1631 (the above-mentioned summons from the Royal Tribunal) and therefore after the "War at the Mouth of the Vistula." After some time, Janikowski stopped using this title in documents - thus clearly indicating that in fact he did not have the right to use such a title. It is certain however that the action he undertook had opened the way to further honours as a landowner and other honours in the Tczew county. On $31^{\text {st }}$ August 1632, he was noted for the first time as lay judge of Tczew. ${ }^{117}$ This was an acknowledgement of his services and status of landowner. This was however the lowest rank of office in Royal Prussia.

The conflict between J. S. Janikowski and the townsmen of Gdańsk did not end with this amicable resolution. In February 1635, J. S. Janikowski took six horses belonging to one Jacob Bell, local lumberjack, onto the public highway in Pruszcz, later claiming in court that he had himself earlier been robbed by Bell and other citizens of Pruszcz of timber from the forests of Pawłowo. In reaction, the town authorities sent 25 soldiers with bombards, muskets and pistols to Pawłowo and they plundered the manor house and got the horses back. ${ }^{118}$ This conflict was later portrayed as a form of boundary dispute and J.S. Janikowski could again count on the support of the local justice system. ${ }^{119}$ The conflict between him and the town was finally ended by an agreement of $28^{\text {th }}$ May, 1637 , according to which in return for resignation of his new claims against the town, Jan Stanisław would obtain an interest free-loan for one year of 1500 zlotys. ${ }^{120}$ Janikowski was already

116 W. CzAPliński, Zatarg z Batorym, p. 610.

${ }^{117}$ Urzędnicy Prus Królewskich, p. 161. See also: Zbigniew Naworski, Szlachecki wymiar sprawiedliwości w Prusach Królewskich (1454-1772). Organizacja i funkcjonowanie, Toruń 2004, p. 252. In the years 1635-1636 several titles appear beside J. S. Janikowski's name, apart from the previously mentioned position as a lay judge, others include "praefectus excubiarum" - "guardian" - and in 1638, even more broadly "Excubiarium et Sacrae Regiae Mttis Praefectus", but he no longer used the title captain. See, for example, APGd, document number 300, 52/950, pp. 55, 63. After the death of J. S. Janikowski he was quoted in the municipal records of Brodnica (20 ${ }^{\text {th }}$ February 1643$)$ in a document allegedly issued by him, in which Jan Stanisław called himself - in Polish - "His Majesty’s Major" (see ibid., document number 300, 52/949, p. 111). The problem is that this was probably another of the forgeries of his brother. See footnote 136.

${ }^{118}$ APGd, document number 300, 52/948, pp. 75-76, 81. In the documentation there is information on the felling of 360 trees.

${ }^{119}$ Ibid., document number 300, 52/948, pp. 83-94.

120 The contract on the loan was drawn up on 28th May (see APGd, document number 300, 52/948, p. 95), while the matter was entered into the Kämmereibuch a day later, see Ibid., document number 300, 12/71, p. 199. 
at that time elected as a representative from Pomerania to the Sejm of the Rzeczpospolita, maybe this was a form chosen by the town of placating the man. This became important during the course of the ongoing conflict with king Władysław IV over his attempts to impose additional customs duties on the maritime trade. Less than a week later, on the $3^{\text {rd }}$ June there was to be an extraordinary sitting of the Sejm and Janikowski's participation in it was noted on $12^{\text {th }}$ and $15^{\text {th }}$ June, when matters concerning the Treasury were being debated, (including the jurisdiction of the Radom Tribunal) and matters concerning the Lębork-Bytów fief. He did not however speak on the $13^{\text {th }}$ June when complaints were made against Gdańsk. ${ }^{121}$ His activities in the Chamber of Representatives in the above-mentioned matters led to his nomination as a delegate for the Pomeranian voivodship to the Crown Revenue Court. ${ }^{122}$ In the difficult period for Gdańsk, over the next few months during which the port was first blockaded by Władysław IV’s fleet of privateers, and then the intervention of a Danish fleet in order to restore access (December 1637), the matter of the rebellious city was raised first at the general regional Sejm of Prussia (February 1638), followed by discussion in the Sejm in Warsaw (March 1638). Jan Stanisław Janikowski then obtained from the municipal funds (recorded $1^{\text {st }}$ March) a sizeable financial gift of 50 Reichstalars (as he scrupulously noted, the equivalent of 225 Prussian grywnas). Maybe this was another attempt to persuade J. S. Janikowski to support the town despite his earlier disfavour. ${ }^{123}$

Despite this obvious manoeuvring between the city and the king, J. S. Janikowski did not lose - at least initially - the grace of Władysław IV, and with the unification of the lands of Lębork and Bytów to Royal Prussia (and the Crown) there arose a good opportunity for him to take advantage of his position. In a document of $2^{\text {nd }}$ July 1638, Jan Stanisław, lay judge of Tczew and "guardian of His Royal Majesty" came into full possession of the royal village of Krosnowo in the Bytów prefecture, lying to north of Bytów and Borzytuchom, and this was certified by the entry into the municipal books of Skarszewy of the privilege of Władysław IV). The privilege specifically notes that this was due to the help that J. S. Janikowski had given his father, Sigismund III, during the "Prussian" war. ${ }^{124}$ A few months

${ }^{121}$ Przemysław Paradowski, W obliczu „nagłych potrzeb” Rzeczypospolitej. Sejmy ekstraordynaryjne za panowania Władysława IV, Toruń 2005, pp. 222-223, 247.

${ }^{122}$ Trybunał Skarbowy Radomski (Volumina Legum. Przedruk zbioru praw staraniem XX Pijarów w Warszawie od roku 1732 do roku 1782 wydanego, vol. 3, Petersburg 1859, p. 434. See also: K. NIESIECKI, op. cit., pp. 435).

${ }^{123}$ APGd, document number 300, 12/70, pp. 109. The Kämmereibuch does not explain the reason for this gift. It should be emphasized that the city was a period of intense negotiations in yet another case - the so-called "controversy with the Prussian nobility" ("Controversiae mit Ritterschaft") over the acquisition and possession of property by the burghers of Gdańsk. The issue of the claims for Łostowice - the former estate of a knight - could therefore be used by J. S. Janikowski to obtain from them another monetary equivalent. On the matter of Władysław IV's maritime policy, see also: W. CzApliński, Spory z Władysławem IV na tle jego polityki morskiej, [in:] Historia Gdańska, vol. 2, pp. 645-654.

${ }^{124}$ APGd, document number 300, 52/950, pp. 97-100. 
later ( $5^{\text {th }}$ August 1638), however, Jan Stanisław along with his youngest brother, Krzysztof Stanisław and accompanied by his stepson, Jacob Pusch, took part in a raid of the village Chmieleniec in the land of Lębork, the inherited estate of Tomasz Chmieliński (see below). Maybe participation in this crime, after which all the participants were punished by the issuing of an infamia, was the reason for the loss of rights to Krosnowo. The following year Colonel Eliasz Arciszewski had Janikowski "driven out" of Krosnowo. ${ }^{125}$ A document dated 14th February 1640 in the records of the municipal court in Skarszewy assigns power of attorney to Andrzej Stanisław Janikowski whose older brother entrusted him with the task of recovering the lost property. ${ }^{126}$ At the same time, defending himself from the punishment of infamia, and already engaged in collusion with the activities of his brother, the forger, Jan Stanisław received on $31^{\text {st }}$ December 1640 a "safe conduct" letter from the king for himself and his stepson and entered it into records of the municipal court in Skarszewy on the $14^{\text {th }}$ January the following year, ${ }^{127}$ little more than a week after in the same court the counterfeit safe conduct of his brother came under scrutiny (see below).

The temporary success of a political nature and in the public sphere did not protect Janikowski from falling into new financial trouble - and perhaps even accelerated it. This was exploited by Jan Stanisław's stepson, Jacob Pusch. On $30^{\text {th }}$ March 1639 he took part in several legal operations in the court in Skarszewy, he paid his stepfather 4000 florins for the purchase of the Hagenbude inn in the village of Orunia, ${ }^{128}$ he then lent him 12000 florins against his future inheritance and declared that he would repay Janikowski's not inconsiderable debts amounting to a further 40000 Polish zlotys, gaining from him a written assurance of succession in Pawłowo. ${ }^{129}$ The document of ownership (intromisja) ceding Pawłowo to Jacob Pusch and citing its total value as 52000 zlotys was issued on $16^{\text {th }}$ March 1639 , but was entered into the records of Skarszewy municipal court only on $30^{\text {th }}$ December that year. ${ }^{130}$ The actual transfer of ownership of Pawłowo took place - as the later court records were to show - on $3^{\text {rd }}$ October $1639 .{ }^{131}$ The action taken did not end the matter, moreover, on the contrary - this led to conflict between J. S. Janikowski and his wife Barbara, the mother of Jacob Pusch. On 14 ${ }^{\text {th }}$ June 1640, Barbara lodged a complaint about her husband before the court in Skarszewy of failure

${ }^{125}$ Colonel Eliasz Arciszewski gave great service to king Władysław IV during the Smolensk War of 1632-1634; he gained experience as an officer in the Thirty Years War - fighting on the side of the Protestant camp, see J. K. DACHNOWSKI, op.cit., p. 216. His merits, and status as an officer were indisputable.

${ }^{126}$ APGd, document number 300, 52/951, pp. 21-22.

${ }^{127}$ Ibid., pp. 83-86.

${ }^{128}$ The location of this inn has not been identified.

${ }^{129}$ APGd, document number 300, 52/950, pp. 109-112, 117-120, 121-128. Collectively, the same documents - see ibid., pp. 129-140, 141-152.

${ }^{130}$ Ibid., pp. 173-174.

${ }^{131}$ Ibid., document number 300, 52/951, p. 51. 
to comply with the agreement concluded with her son the previous year. ${ }^{132}$ In the course of this new conflict and the case against Jan Stanisław - before the matter was finished - he died before $14^{\text {th }}$ March $1641 .^{133}$

Perhaps an issue that complicated the relationship between stepfather and stepson (and his mother), were the claims of the two younger brothers of Jan Stanisław, Krzysztof Stanisław and Andrzej Stanisław. In a document of April 16 ${ }^{\text {th }}, 1640$ drawn up in Gdańsk and then copied into the records of the municipal court of Skarszewy, Jan Stanisław (claiming as a reason his "brotherly love" and in order to remunerate his younger male siblings for previous "wrongs"), committed himself and his sole heir - his stepson Jacob, to a so-called submisja, sanctioning all the agreements and contracts concluded earlier by these younger brothers in relation to the property of Pawłowo. ${ }^{134}$ Krzysztof Stanisław promised moreover that after the infamia imposed for the attack on the village of Chmieleniec was ended, he would repay the 3000 zlotys of his earlier obligations. ${ }^{135}$ In this document, Jan Stanisław allowed the recording of these obligations to his brothers after his death in any town court in the Kingdom of Poland "when it will be their will." ${ }^{136}$ As a result of this, Krzysztof Stanisław chose Brodnica, quite a long way away from Gdańsk, and wrote there the above-mentioned document on $20^{\text {th }}$ February 1643 , together with documenting a personal assurance from Pusch sanctioning all the obligations of his stepfather, ostensibly dated $12^{\text {th }}$ November 1639 , and thus before his obtaining Pawłowo. ${ }^{137}$ Jacob Pusch never accepted, however, any claims on the behalf of his future main adversary, considering that were fundamentally groundless. He was the first, on $14^{\text {th }}$ March 1641, who took over the inheritence of his stepfather, Pawłowo on the basis of the document of ownership (intromisja) which he had

${ }^{132}$ Ibid., pp. 1-4.

${ }^{133}$ Ibid., p. 51. In the publication Urzędnicy Prus Królewskich, p. 161, there is an unclear reference to his dying before $3^{\text {rd }}$ December 1641. In any case, he cannot have been a member of the Sejm of the Rzeczpospolita in 1647 as P. Paradowski, cited above, suggests (see P. PARADowsKi, op.cit., p. 247). This must have been a different Jan Stanisław Janikowski.

${ }^{134}$ APGd, document number 300, 52/949, pp. 111-114.

${ }^{135}$ Ibid., pp. 114-115. The document is dated to Easter Saturday 1640 (14 $4^{\text {th }}$ March 1640). The sum of 3000 zlotys would be in agreement with the amount that Jan Stanisław owed Krzysztof Stanisław after his obtaining the rights to inherit Pawłowo in 1638. Already ( $6^{\text {th }}$ December 1639), Krzysztof Stanisław reminded his brother of this obligation in a document issued in Piotrków (Trybunalski), see APGd, document number 300, 52/948, pp. 101-102. It should be noted (see below), that all these legal documents were procured while Krzysztof Stanisław was already under the infamia, which he was using his counterfeit "safe conduct" letter from the king to defend himself against.

${ }^{136}$ APGd, document number 300, 52/949, pp. 114-115.

${ }^{137}$ Ibid., pp. 116-121. The witnesses of this document were two members of the Janikowski family, Andrzej Stanisław (the brother of Jan Stanisław and Krzysztof Stanisław), who was dead by 1643, and the above-mentioned Pawel Stanisław, a cousin. It is worth noting the distance between Brodnica and Skarszewy. In the jurisprudence of Royal Prussia, jurisdiction was usually related to the place of residence of a nobleman, both in the castellan as well as the regional courts, but of course there were exceptions. See Z. NAWORsKI, op. cit., pp. 74, 128. 
earlier obtained. ${ }^{138}$ On June $30^{\text {th }}, 1641$, there was also a similar document assigning the rights to the assets of the widow of the lay judge, Barbara Janikowska (née Olrychsen). ${ }^{139}$ The most interesting fact though is that according to the accounts of eye-witnesses recorded in the records of the municipal court of Skarszewy (17 ${ }^{\text {th }}$ August, 1641), concerning the later raid of Krzysztof Stanisław Janikowski on Pawłowo in July 1641, the body of Jan Stanisław had not been buried, but the coffin containing his body was still in a "chamber" in the house in Pawłowo. ${ }^{140}$ Probably therefore the presence of the former owner of Pawłowo - treated in this way - was in some manner a guarantee of the state of legal limbo, just in case, because he still remained in residence on his property.

\section{THE MIDDLE BROTHER - ANDRZEJ STANISŁAW JANIKOWSKI}

Andrzej Stanisław and Krzysztof Stanisław, the younger brothers of Jan Stanisław, appear in court records as the subjects of an agreement of $2^{\text {nd }}$ August, 1625. They had pawned their part of the Pawłowo property to the above-mentioned Philip Lacke for a sum of 6000 zlotys. Krzysztof Stanisław was still a minor and was represented by Andrzej Stanisław, and in a separate document, their mother Katarzyna Janikowska (née Sobanska) recorded her agreement to the transaction. ${ }^{141}$

Of all the male members of the Janikowski family, we know the least about Andrzej Stanisław, the middle brother of the forger Krzysztof Stanisław. The numerous inclusions in Latin in the documents written by him personally testify that he received some education. In 1620s he was at the court of Prince Zbaraski (Krzysztof, crown equerry, who died in 1627, or Jerzy, Castellan of Cracow, who died in 1631 as last of the Zbaraski family). ${ }^{142}$ Jan Stanisław, the eldest of the brothers, had to send him 100 florins for the payment of a commitment made to a Mr Dadźbóg. ${ }^{143}$ There is preserved a letter (27 ${ }^{\text {th }}$ July 1630$)$ in which Andrzej Stanisław complains to Krzysztof Bystram, the heir to the property "Golempkowo" (Gołębiewko?) that he and his brother felt neglected by their eldest brother, Jan Stanisław, who did not feel any obligation to look after them. He wrote that his brother did not help them financially, that neither he nor Krzysztof Stanisław have "eaten bread with him a hundred times in all those years" and as for help with upkeep, they had received only "a hundred zlotys, and these would not have sufficed had not somebody else given us all but one set of clothes." Andrzej Stanisław added that both of the brothers were then spending more time with their sister than with their older brother in Pawłowo (the letter was written in Liniewko, most probably

${ }^{138}$ APGd, document number 300, 52/951, pp. 51-52.

${ }^{139}$ Ibid., pp. 47-50.

${ }^{140}$ Ibid., pp. 75-76.

${ }^{141}$ Ibid., document number 300, 52/949, pp. 29, 33-34.

${ }_{142}$ See K. Niesiecki, op. cit., t. 10, pp. 118-121.

${ }^{143}$ According to Niesiecki's armorial (Herbarz, op. cit., vol. 3, p. 298) a nobleman from the Lublin region, but also from Polotsk and Mstislaw in the Grand Duchy of Lithuania. 
the property of the Sielski or Rowiński family). ${ }^{144}$ In another of his letters, dated September $1^{\text {st }}, 1630$, he asked Philipp Lacke, by then probably a royal secretary, how much pawning of Pawłowo by Jan Stanisław in 1624 had depleted his (and Krzysztof Stanisław's) inheritance after the death of his father. ${ }^{145}$ After the death of the mother, Katarzyna (née Sobańska) Jan Stanisław made a commitment in the records of the municipal court in Skarszewy (23 $3^{\text {rd }}$ July 1631) to Andrzej Stanisław in which he guaranteed him the amount owed to the mother from the dowry, and because it was then in the form of a loan granted to the Stanisławskis (related through his sister, Elżbieta), they were obliged to ensure the repayment, pledging the sum secured by their property at Boroszewko near Godziszewo. ${ }^{146}$ The same day, Andrew sold his part of Pawłowo to his elder brother, obtaining for his share of the property a fair, at least formally, price of 8000 zlotys. This act was entered into the books of the municipal court of Skarszewy. ${ }^{147}$ The Stanisławski family, especially after the death of Elżbieta (née Janikowska), were reluctant, however, to satisfy the claims of the Janikowskis, therefore Andrzej (and Jan Stanisław) obtained a judicial decree, entered in the books of the Skarszewy court on $14^{\text {th }}$ June 1636 ordering the immediate repayment of the amount due to Andrzej or - as compensation for it - handing over Boroszewko. ${ }^{148}$ It seems that even this decree remained only declarative, and after the unexpected death of his brother-in-law, Andrzej Stanisław became the guardian of orphans (including children from the first marriage of Jan Stanisławski with Justyna née Szorc and of course the descendants of his own sister, Elżbieta) and thus became in any case the custodian of Boroszewko. It seems that Andrzej Stanisław did not fulfil the role of guardian of his nephews very well, to their prejudice, and treating Boroszewko as his own property. Because of this, complaints were lodged by another of his brothers-inlaw, the burgrave of Skarszewy, Andrzej Sielski, widower of his sister Dorota (entry in the records of the municipal court in Skarszewy from February $\left.14^{\text {th }}, 1639\right) .{ }^{149}$

It seems that Andrzej Stanisław was still alive when his elder brother Jan Stanisław died in 1641. In the light of the documents about Krzysztof Stanisław described below, it seems that Andrzej died from unidentified causes in the next few months, and before June or July 1641 when conflict broke out about Pawłowo between the forger and the widow and stepson of Jan Stanisław. ${ }^{150}$ The document

${ }^{144}$ APGd, document number 300, 52/955, pp. 3-6.

${ }^{145}$ Ibid., pp. 7-10.

${ }^{146}$ Ibid., document number 300, 52/948, pp. 55-58. See also: ibid., document number 300, 52/950, pp. 5-8.

${ }^{147}$ Ibid., document number 300, 52/950, pp. 13-16.

${ }^{148}$ Ibid., pp. 45-48.

${ }^{149}$ Ibid., pp. 153-154.

${ }^{150}$ In the "autopsy" of the July attack of Krzysztof Stanisław on Pawłowo cited above, there is a mention of the bodies of "the Janikowski men" (plural) in a "chamber" in the manor house at Pawłowo. This means that this did not only concern the body of Jan Stanisław, although it was only his name mentioned (because a stray pistol shot had perforated the lid of his coffin). A slightly later 
of "submission" of 1643 in the court records of Brodnica discussed above refers to him, without using the formula olim (as it quoted the obligation of Jan Stanisław of 1640), but was signed only by Krzysztof Stanisław. Andrzej Stanisław never married, so did not leave behind him any descendants. According to the account, not entirely reliable, of Krzysztof Stanisław, it was his sister-in-law, Barbara Janikowska (née Olrychsen), who removed the body of her second husband (Jan Stanisław) and Andrzej from the family tomb on their property at Pawłowo and transporting them in sacks to the marketplace of Skarszewy, placed them on display there to be shamed and ridiculed, and only later after the local priest intervened were they buried in the parish church there. ${ }^{151}$

\section{IN THE SHADOW OF HIS BROTHERS: THE FIRST CRIMES OF KRZYSZTOF STANISEAW JANIKOWSKI}

Józef Rumiński's biographical note in the Polish Biographical Dictionary suggests that Krzysztof Stanisław Janikowski was born about 1615. It turns out, however, that while he was a minor in 1625, four years later he was already an adult, capable of undertaking independent legal acts. ${ }^{152}$ The first known deception he undertook was the extortion of money, horses and carriage from the Kalisz Franciscans. ${ }^{153}$ It is not known precisely when he did this. The above-mentioned documents and letters of 1625,1629 and 1630 show that he was present in the Tczew county in that period. There is no record of any legal activity by him there in the years 1631-1636. Maybe he was outside Prussian territory in those years, but it is difficult to imagine that he spent all that time as a novice in Kalisz. In the mendicant orders, a novitiate seldom lasted more than a year, or at the most two. His sending away so far from Pawłowo confirmed not only the family ties with the Kalisz region, but it could also have been done as a kind of punishment and educational experience for the wayward youth, and at the same time comprise

document, the act of ownership (intromisja) for Pawłowo (23 $3^{\text {rd }}$ November 1641) of their sister Barbara Tokarska (née Janikowska), clearly states that she is moving there to the property inherited from her dead brothers Jan, Andrzej (but also Krzysztof - who as we know was only dead to civil society due to being under the infamia). See APGd, document number 300, 52/951, p. 89.

${ }^{151}$ Ibid., document number 300, 52/948, pp. 145-146 (document issued 16th October 1646, inscribed in the records of the Skarszewy municipal court). Because this information corresponds with the information about the storage of the bodies of these two male members of the Janikowski family in a chamber in the manor house at Pawłowo, this was not the desecration of a tomb, but - it cannot be denied - an attempt full of malice, wickedness and personal injury to pass the duty of burial onto others.

${ }^{152}$ Ossolineum Library, manuscript 3179 II (the records of the lay court of Kościerzyna for the years $1622-1629)$, p. 189. In a document copied into this book on $21^{\text {st }}$ June 1629 , Krzysztof Stanisław ceded his rights to parts of Pawłowo to Andrzej Stanisław, his own brother. In the light of this document Krzysztof Stanisław would have therefore been born about 1605. Of course it is possible to surmise that perhaps the reason for the agreement was the intention of Krzysztof to enter the monastic order, which is did soon after.

${ }^{153}$ J. Rumiński, Janikowski Krzysztof Stanisław, p. 518. 
a reasonable and rational option for the future. Jan Stanisław, the oldest of the brothers made a career in administration and had some kind of contact, perhaps, with the army. Attempts were made to promote Andrzej Stanisław as a courtier, but the youngest was destined to join the clergy. Maybe Krzysztof Stanisław had first made an attempt to become a teacher, but it has to be said, to judge from his letters, that of the three brothers he was the weakest in his knowledge of Latin, and - like his older brothers - he did not speak German and his Polish was poor. At a later date, when his forgeries were discovered, his weak linguistic knowledge was ridiculed. In the creation of his forged documents, others composed the Latin and German texts for him.

In September 1637, Krzysztof Stanisław (still a minor, because he appears together with his brother Andrzej Stanisław), is mentioned in an act of appeal against a commitment of Jan Stanisław to his two younger brothers, of the amount of 100 zlotys. ${ }^{154}$ On March $8^{\text {th }}$ however, he too (as had done Andrzej Stanisław seven years earlier) sold his share of Pawłowo to Jan Stanisław for the same amount as the earlier transaction, 8000 zlotys, indicating that the whole sum was delivered at once into his hands. ${ }^{155} \mathrm{On}$ the same day, however, a document was drawn up, in which Jan Stanisław records that he borrowed the sum of 3000 zlotys from Krzysztof Stanisław. ${ }^{156}$ Krzysztof Stanisław had, above all, a good relationship with his middle brother. In the above mentioned case of his conflict with Andrzej Stanisław about him not looking after the welfare of his nephews, there appears the complaint of a nobleman, Łukasz Wipczyński, giving evidence in Skarszewy on $23^{\text {rd }}$ February 1639, that during the absence of Andrzej Stanisław (who was at this time in Piotrków seeing to matters connected with his wards), Krzysztof Stanisław came to Boroszewko, and "borrowed" a pair of oxen, which he later did not give back. ${ }^{157}$

The joining in 1637 of Lauenburg (Lębork) and Bütow (Bytów) land to Royal Prussia was to prove a training ground for the first of Janikowski's serious frauds. Perhaps Krzysztof Stanisław became interested in this way to earn extra money quickly after his older brother, Jan Stanisław, obtained title to the village of Krosnowo. A few months later, he became the leader of an escapade that on $5^{\text {th }} \mathrm{Au}$ gust 1638 involved an attack on the village Chmieleniec in the land of Lębork, the inherited estate of Tomasz Chmieliński. ${ }^{158}$ Janikowski was accompanied among others, Jan Stanisław and Paweł Janikowski, Jacob Pusch, Andrzej Tokarski. ${ }^{159}$

${ }^{154}$ APGd, document number 300, 52/950, pp. 53-54.

${ }^{155}$ Ibid., pp. 55-58.

${ }^{156}$ Ibid., pp. $67-70$.

${ }^{157}$ Ibid., pp. 171-172.

${ }^{158}$ A village in the parish of Bożepole Wielkie, which was however some considerable distance from Krosnowo.

${ }^{159}$ APGd, document number 300, 52/951, s. 44. The identity of the brothers, their cousin (Paweł) and stepson (Pusch) is unequivocally confirmed by the place of the later delivery of a summons in the name of Chmieliński to them all, which was the village of Pawłowo (this ocurred on $16^{\text {th }}$ June 1639 see ibid., document number 300,52/950, p. 166). Andrzej Tokarski was however certainly a relation 
It came to the use of weapons, including a bombard. Tomasz's wife, Anna, was injured, Tomasz was imprisoned for some time, there was considerable damage, estimated then at 6000 zlotys. ${ }^{160}$ It seems that the aim of the expedition was to take over a certain part of the property. A few weeks after the incident, the parties entered the path of a legal investigation of their arguments.

On $19^{\text {th }}$ October 1638, Krzysztof Stanisław Janikowski sued the "notorious" Jan Dąmbrowski, citizen of Gdańsk, before the regional court in Starogard (where the lay judge was his brother, Jan Stanisław), in order to prove that he was a member of the nobility, as the legality of this claim had been challenged. Janikowski intended in this way to preventively harm the reputation of Dąmbrowski, who had publicly accused him in Lębork and Bytów to the royal commissioners of usurping by force the rights to certain land in the villages of Chmieleniec and Trzebielin (Strzebielino). ${ }^{161}$

In January 1639, Krzysztof Stanisław then presented in the court in Starogard the privilege of Władysław IV, which confirmed the change of ownership of the Borno (or Borne) inn and the fields of Hamry in those villages to him from their previous owner Tomasz Chmieliński. This document bears the date $1^{\text {st }}$ June 1638. ${ }^{162}$ Chmieliński questioned the validity of this document and took the matter before the municipal court of Skarszewy (17 $7^{\text {th }}$ May 1639), and the latter - headed by Paweł Działyński, the voivode of Pomerania - issued a summons to all the parties involved in the conflict, both the organizers of the attack as well as witnesses for the victims. The whole procedure was described in records added to the municipal court records of Skarszewy on $5^{\text {th }}$ July $1639 .{ }^{163}$ The case then came under the jurisdiction of the voivode of Malbork, Samuel Konarski. The punishment of an infamia was announced in Malbork, this time by Michał Strzembowski, the instigator of that governor. Krzysztof Stanisław defended himself against this very cleverly by means of a "letter of safe conduct" issued by Władysław IV, and entered into the municipal books of the town of Brodnica on the $22^{\text {nd }}$ June 1639, thus six days after obtaining the summons in Pawłowo. ${ }^{164}$ This desperate act however only temporarily defended him from the consequences of the attack on Chmieleniec. The punishment of infamia of the forger and his companions was announced in a verdict of the Tribunal in Piotrków $\left(24^{\text {th }}\right.$ February 1640$)$ and then entered into

(brother, son?) of Grzegorz Tokarski, the brother-in-law of Krzysztof Stanisław. He received his summons on 19th June at Perlino, a village near Gniewino, several dozen kilometres to the north of Bożepole Wielkie.

${ }^{160}$ APGd, document number 300, 52/951, p. 41.

${ }^{161}$ Ibid., document number 300, 52/949, pp. 93-96.

${ }^{162}$ Ibid., pp. 107-110. Obviously it was only a copy that was included in the court records. This would be proof of one of the earliest known forgeries created by Krzysztof Stanisław. The king had no reason whatsoever to have given him these lands.

${ }^{163}$ APGd, document number 300, 52/950, pp. 161-170.

${ }^{164}$ Ibid., document number 300, 52/949, pp. 101-104. See J. Rumiński, Janikowski Krzysztof Stanistaw, s. 518, who also thought that this "safe conduct" had been forged. 
the records of the municipal court of Skarszewy (24 $4^{\text {th }}$ March 1640). ${ }^{165}$ In turn on the $3^{\text {rd }}$ January 1641 in the regional court in Brodnica the forgery by Krzysztof Stanisław of the "safe conduct" of Władysław IV was demonstrated, the documentation of which was six days later ( $8^{\text {th }}$ January) also added to the records of the municipal court of Skarszewy. ${ }^{166}$

Being in dire straits, the youngest of the brothers, already at the end of 1639, as mentioned above - launched at the same time a legal "offensive" against his brother Jan Stanisław (or perhaps more accurately - against the designated heir of the latter, Pusch), aimed at obtaining the outstanding amount of 3000 Polish zlotys owed for the portion of the Pawłowo property for which not all the payment had been received. To this end, he made a visit in that year to Piotrków and in April 1640 to Gdańsk and Skarszewy. ${ }^{167}$ When Jan Stanisław died and Pawłowo was in March to June 1641 in the hands of his widow and her son from her first marriage, Pusch, Krzysztof Stanisław, while still in a state of 'infamia' attempted an armed occupation of the property between $30^{\text {th }}$ June and $19^{\text {th }}$ July 1641 . In the course of this he plundered the place, removing almost all the moveable goods from it, including a library worth nearly 30000 Polish zlotys (the widow claimed that it was her personal property), weapons, clothes, underwear, livestock, food supplies and farm and agricultural tools. Together the losses were then estimated as close to 9000 Polish zlotys. ${ }^{168}$ In the course of further legal action, the widow was able to demonstrate before the same court that the amount of 3000 florins due to her brotherin-law had long since been settled (Act of August ${ }^{\text {st }}, 1641$ ). ${ }^{169}$ Ultimately was she who retained, for the moment, that estate, complaining in a subsequent document laid before the court that friends of her brother-in-law were threatening her with death for it ( $3^{\text {rd }}$ December 1641). ${ }^{170}$ In the same time, Paweł Działyński, the governor of the Pomeranian province, decided to convene the militia of the nobility of their land, in order to effect the capture of Krzysztof Stanisław, who it was felt was becoming a growing threat to public order $\left(1^{\text {st }}\right.$ December 1641$) .{ }^{171}$ It seemed, therefore, at this point, that Janikowski - a brawler, common criminal, and maybe even shameless forger of royal documents - would not escape severe punishment.

${ }^{165}$ APGd, document number 300, 52/951, pp. 5-12. Other copies of this document: ibid., pp. 33-44; document number 300, 52/954, pp. 23-46, 57-58. In connection with this matter, one could also mention that K. S. Janikowski was also in this time engaged in a property-claim conflict with the Przebendowskis and here also there was talk of the forging of documents, see Ibid., document number 300, 52/954, pp. 11-18.

${ }^{166}$ Ibid., document number 300, 52/951, pp. 53-56.

${ }^{167}$ See footnote 133.

${ }_{168}$ APGd, document number 300, 52/962, pp. 71-72. See also: J. Rumiński, Fałszerstwa, p. 53.

${ }^{169}$ APGd, document number 300, 51/951, pp. 65-68. She was also, moreover, at this time in a dispute with another heiress of her second husband, Barbara Janikowska (née Tokarska), who in November 1641 even managed to gain an ownership document (intromisja) to Pawłowo, see ibid., document number 300, 52/951, pp. 71-78, 81-82, 89-90.

${ }^{170}$ Ibid., 87-88.

${ }^{171}$ Ibid., document number 300, 52/948, pp. 103-104. 
Yet, in unexplained circumstances, he managed to get patronage at the royal court and in Warsaw received a royal mandate, dated $30^{\text {th }}$ August 1642 and apparently signed by the hand of the king himself, bearing the royal seal and countersigned by the king's secretary Zygmunt Suliński (and therefore not issued by the office of the Crown, but privately). In this document, the king ordered the city council of Gdańsk to award the entire inheritance left by Jan Stanisław Janikowski (and not only Pawłowo) to Krzysztof Stanisław his "natural" heir. ${ }^{172}$ In a second document, with the same date and place of issue and the same addressee, the king placed all the blame on Jacob Pusch, declaring him guilty of appropriating the Janikowski inheritance and declared him under an infamia. ${ }^{173}$ Here there is no doubt about the authenticity of both documents, which has never been questioned. As a result of the changed situation, on $20^{\text {th }}$ September 1642, Janikowski presented in Skarszewy a new "safe conduct" from the king that was countersigned by the great Crown Chancellor Jerzy Ossoliński (with the date $9^{\text {th }}$ September). ${ }^{174}$ This turnabout in circumstances is difficult to explain in any rational manner, unless it was already the case that Krzysztof Stanisław had had the opportunity to offer the king (or at least the Great Chancellor), his services and the offer was accepted. In the eyes of the Prussian nobility, he was still an outlawed brawler, especially since he had committed further crimes and robberies during the continuation of his private war with his sister-in-law Barbara Janikowska (née Olrychsen) over Pawłowo. At the turn of 1642 and 1643, together with the above-mentioned Jane Sławski he made an unsuccessful attempt to take over that property too. Somewhat earlier (12 ${ }^{\text {th }}$ August 1642), Pawłowo had become the property of Tobiasz Arciszewski as payment of a debt owed by Barbara, the widow of the lay judge, Jan Stanisław. ${ }^{175}$ A few months later on $12^{\text {th }}$ May 1643, Krzysztof Stanisław collecting together a "group of ruffians" composed of local gentry - among them was his cousin Stanisław Janikowski and sister, Barbara Tokarska - managed to successfully occupy Pawłowo, and all Arciszewski could do was to make a complaint to the court in Skarszewy. ${ }^{176}$

After a series of these brutal excesses Janikowski, however, preferred for a time to go abroad, to West Pomerania, to the land of Słupsk. He stopped in Motarzyno, the property of the Zitzewitz family, just outside the boundary of the territory of Bytów, and close to Krosnowo, the property which his brother had failed to retain. On 25 th November 1643, in Motarzyno he married Anna, the daughter of the innkeeper, Adam Montewicz, once a peasant of Chełmno. ${ }^{177}$ We may add to the characterisation of this king of forgers of the Sarmatian period that he was genuinely in love with his "Anusia" and even wrote poems for her. Of the three survi-

\footnotetext{
${ }^{172}$ Ibid., document number 300, 52/956, pp. 1-4.

${ }^{173}$ Ibid., pp. 5-8.

${ }^{174}$ Ibid., document number 300, 52/951, pp. 111-114. See also: ibid. pp. 127-130.

${ }^{175}$ Ibid., pp. $123-126$.

${ }^{176}$ Ibid., pp. $187-190$.

${ }^{177}$ J. Rumiński, Fałszerstwa, p. 52; idem, Janikowski Krzysztof Stanisław, p. 518.
} 
ving - rather clumsy - poetic works extant today, two are love poems dedicated to her, the third has religious and Marian content. ${ }^{178}$

It was in Motarzyno in the late autumn of 1643 or the beginning of 1644 that the idea appeared to create and circulate forgeries of legal documents on a scale and of a quality never seen before - a whole chest of documents. At a later date, Janikowski himself linked these two events, citing for example in the title of the register of the income from the sale of these documents cited by Rumiński that it was a Register begun in the year of Our Lord 1644 of what privileges I took from those found in the walls of Motarzyno in the powiat of Stupsk, since it was there that I and my Anusia were wedded on St Catherine's Day [25 th November] $1643 .{ }^{179}$ The first signals of the existence of these documents appeared in the first half of 1644 . In the course of the three successive years, these privileges created an incredible sensation on a scale not only of the province, but also the Polish Republic, and an attempt was even made to use them in the international negotiations ending the Thirty Years War. ${ }^{180}$

\section{CONCLUSION}

From the above analysis, it can be concluded that Krzysztof Stanisław Janikowski began his life of crime at a very early age; well before the alleged discovery of a chest of documents in the castle at Motarzyno, he was regarded as an impudent liar, swindler and unworthy of respect or honour, an outlaw under the penalty of an infamia. It took some time for such an attitude to life to develop, in the course of long-running disputes and manoeuvring before the courts, it was further fostered by his father and continued by his brothers, especially Jan Stanisław the oldest, and apparently the most well-situated in the elite society of the time. In the whole of these early activities which were not always in accord with the law, attention is drawn to the long and growing conflict with the city council and burghers of Gdańsk, which explains the particular doggedness of the forgery activities of Krzysztof Stanisław addressed to matters concerning this city, but also the great degree that Gdańsk was involved in unmasking his activities. The Janikowskis were resourceful people full of ambition, but not quite able to cope with the principles of the economic realities of their times, thus their constantly growing debts due to mortgage of the village of Pawłowo which had been gained with such difficulty, but the possession of which guaranteed them the position of landowners.

Jan Stanisław tried to save his position by marrying the townswoman Barbara (née Olrychsen) and then selling the property for the debts of her son, and his stepson, Jacob Pusch. The methods and activities of Krzysztof Stanisław were more drastic. With ease, moreover, following somewhat in the existing patterns of other members of his family, he resorted to violence and armed occupation of

\footnotetext{
${ }^{178}$ APGd, document number 300, 52/962, pp. 5-7.

${ }^{179}$ J. Rumiński, Fatszerstwa, p. 42.

${ }^{180}$ Ibid., pp. 37-38.
} 
properties, but he soon personally developed a unique skill - producing forged documents and using them before the various regional and municipal courts of Royal Prussia. In the end, it has to be very clearly stated that only the patronage of the royal court and the people around it could, if only temporarily, shield such a disgraced person from being punished, and even accept him into elite company. Behind this stood the personal interests and specific political calculations of his probable patrons.

(transl. by Paul Barford)

Received $28^{\text {th }}$ October 2015

Received in revised form $21^{\text {st }}$ February 2016

Accepted 26 ${ }^{\text {th }}$ March 2016

Dr hab. Sławomir Kościelak, prof. UG

Institute of History

University of Gdańsk

e-mail:doksjk@univ.gda.pl

\section{ABSTAMMUNG, VERWANDTE UND GENESE DER FALSCHUNGS- TÄTIGKEIT VON KRZYSZTOF STANISŁAW JANIKOWSKI}

\section{Zusammenfassung}

Schlüsselwörter: Königliches Preußen, Władysław IV. Wasa, Gerichtsbarkeit, Dokumentenfälscher, Kleinadel - sozialer Auf- und Abstieg

Die Genese und der Verlauf der kriminellen Tätigkeit von Krzysztof Stanisław Janikowski, einem der bekanntesten Dokumentenfälscher in der polnischen Geschichte vor der Teilung der Republik Polen, sind bis heute nicht vollständig ermittelt und analysiert worden. Im vorliegenden Beitrag werden die Abstammung und die familiären Beziehungen dieses Hochstaplers aus dem 17. Jh. charakterisiert, genauso wie die Gegebenheiten, die ihn auf seinen kriminellen Weg brachten, darunter der langwierige finanzielle Konflikt mit dem Stadtrat und den Danziger Bürgern, der seine Familie an den Rand des Ruins brachte. Schuldenspirale, Lavieren vor unterschiedlichen Gerichtsinstanzen, Zwangsehen, Besetzungen, Raub, Gewalttätigkeiten und Morde bildeten eine ganze Litanei an Verfehlungen, die sich die Verwandten des Fälschers, darunter sein Vater Stanisław Janikowski und sein ältester Bruder Jan Stanisław Janikowski, zu Schulden kommen liesen. Der Letzte machte sogar eine Karriere als Politiker und Beamter - er war Landrichter in Dirschau (poln. Tczew), Abgeordneter im Sejm der Republik Polen und Deputierter im Kron-Tribunal. Er lebte jedoch über seine Verhältnisse, was mit der Übernahme seines Vermögens durch die bürgerliche Familie Pusch aus Danzig endete. Im Kampf um das brüderliche Erbe sowie um andere, fremde Güter ergänzte Krzysztof Stanisław Janikowski sein Arsenal an kriminellen Energien um das Fälschen. Obwohl er sogar Dokumente aus der königlichen Kanzlei fabrizierte, schützten ihn gerade der König und seine Beamten, lange bevor 
er der Öffentlichkeit seine Massen-Fälschungsprodukte feilbot, vor der Härte des damaligen Rechtes.

\section{BACKGROUND, RELATIVES AND THE ORIGIN OF THE COUNTERFEIT ACTIVITY OF KRZYSZTOF STANISŁAW JANIKOWSKI}

\section{Summary}

Key words: Royal Prussia, Ladislaus IV, the judicial system, forgers of documents, minor gentry - the social promotion and demotion

The origin and the course of the criminal activity of Krzysztof Stanisław Janikowski, one of the most famous forgers of documents in the history of the Rzeczpospolita in the period prior to the partitions have not been fully examined yet. This article presents the background and family connections of the $17^{\text {th }}$ century swindler, the circumstances which led him to crime, including a long-lasting economic conflict with the Town Council and the burghers of Gdańsk, which eventually led his family to bankruptcy. A debt spiral, prevaricating in front of various judicial instances, forced marriages, robberies, beatings and assassinations constituted the resources frequently used by the relatives of the forger (including Stanisław Janikowski, his father, and his eldest brother - Jan Stanisław Janikowski). The latter even made a career as an official and politician - he became a town councillor of Tczew, a member of Parliament and a deputy to the Radom Tribunal. Living beyond his means led to his estate being taken over by a family of burghers from Gdańsk - the Pusches. Fighting for the legacy of his father and other estates, Krzysztof Stanisław Janikowski turned to forgery. He even falsified the documents from the royal chancery. It was the king and his officials who protected him against the severity of the law long before he revealed to the public his extensive forgery activity. 